\title{
Sequência didática investigativa sobre o tema som: perspectivas para a formação continuada de professores nos Anos Iniciais do Ensino Fundamental
}

\author{
Investigative didactic sequence on the topic of sound: perspectives for the continuing education \\ of teachers in the Early Years of Elementary School \\ Secuencia didáctica investigativa sobre el tema del sonido: perspectivas para la formación \\ continua del profesorado en los primeros años de la escuela primaria
}

Eduardo Lemes Monteiro ORCID: https://orcid.org/0000-0001-8222-1728 Universidade Estadual de Maringá, Brasil

E-mail:emonteiromat@hotmail.com

Polonia Altoé Fusinato

ORCID: https://orcid.org/0000-0002-4698-8574 Universidade Estadual de Maringá, Brasil

E-mail: altoepoly@gmail.com

Andreia Freitas Zompero

ORCID: https://orcid.org/0000-0002-5123-8073 Universidade Estadual de Londrina, Brasil E-mail: andreiazomp@uel.br

Josie Agatha Parrilha Silva

ORCID: https://orcid.org/0000-0002-8778-6792

Universidade Estadual de Ponta Grossa, Brasil E-mail: josieaps@hotmail.com

Salete da Silva

ORCID: https://orcid.org/0000-0001-9072-4712

Universidade Estadual de Ponta Grossa, Brasil E-mail: saletedasilva66@ hotmail.com

\begin{abstract}
Resumo
O ensino de Ciências nos Anos Iniciais do Ensino Fundamental apresenta algumas individualidades em relação as outras etapas de ensino. Uma delas está no fato do docente ser generalista, e quase sempre graduado em Pedagogia, Normal Superior ou curso de formação docente em nível médio, sendo de sua responsabilidade ensinar todas as disciplinas do currículo básico. O presente trabalho objetivou investigar as contribuições de uma sequência didática investigativa seguindo os pressupostos metodológicos de Carvalho (1988) sobre os conceitos básicos relacionados ao som em uma formação continuada desenvolvida em EaD. O estudo de natureza qualitativa e do tipo pesquisa-ação e foi desenvolvida com cinco professores que lecionam nos $3^{\circ}$ anos da rede municipal de Educação da cidade Mandaguari- PR por meio de uma formação continuada básica. Todos os materiais coletados para análise foram interpretados segundo os princípios e procedimentos da análise de conteúdo de Bardin (1977). O resultado de nossa investigação aponta para a existência de lacunas relacionadas aos conceitos básicos do som, visto que esse tema é pouco abordado nas capacitações ofertadas bem, e quando aparecem não são discutidos. As conclusões desse estudo revelam que quando os docentes são convidados a realizar investigações são capazes de realizar análises em um contexto dotado de significados. De tal modo, os docentes se tornam capazes de utilizar conceitos científicos como instrumentos de leitura, compreensão do mundo e significação.
\end{abstract}

Palavras-chave: Ensino de ciências; Formação de professores; Acústica.

\begin{abstract}
The teaching of Science in the Early Years of Elementary School presents some individualities in relation to the other stages of teaching. One of them is in the fact that the teacher is a generalist, and almost always graduated in Pedagogy, Superior Normal or a high school teacher training course, being his/her responsibility to teach all the subjects of the basic curriculum. The present work aimed to investigate the contributions of an investigative didactic sequence following the methodological assumptions of Carvalho (1988) on the basic concepts related to sound in continuing education developed in $\mathrm{EaD}$. The study is qualitative in nature and action-research type and was developed with five teachers who teach in the 3rd year of the municipal education network in the city of Mandaguari-PR through basic continuing education. All materials collected for analysis were interpreted according to Bardin's (1977) content
\end{abstract}


analysis principles and procedures. The result of our investigation points to the existence of gaps related to the basic concepts of sound, as this topic is little addressed in the skills offered well, and when they appear, they are not discussed. The conclusions of this study reveal that when professors are invited to carry out investigations, they are able to carry out analyzes in a context endowed with meanings. In this way, teachers become capable of using scientific concepts such as reading instruments, understanding of the world and meaning.

Keywords: Science teaching; Teacher training; Acoustics.

\section{Resumen}

La enseñanza de la ciencia en los primeros años de la escuela primaria presenta algunas individualidades en relación con las otras etapas de la enseñanza. Una de ellas es que el docente es generalista, y casi siempre egresado de Pedagogía, Superior Normal o de un curso de formación docente de bachillerato, siendo su responsabilidad impartir todas las asignaturas del currículo básico. El presente trabajo tuvo como objetivo investigar los aportes de una secuencia didáctica investigativa siguiendo los supuestos metodológicos de Carvalho (1988) sobre los conceptos básicos relacionados con el sonido en la educación continua desarrollada en EaD. El estudio es de naturaleza cualitativa y tipo investigación-acción y se desarrolló con cinco docentes que imparten docencia en el 3er año de la red educativa municipal de la ciudad de Mandaguari-PR a través de la educación básica continua. Todos los materiales recopilados para el análisis se interpretaron de acuerdo con los principios y procedimientos de análisis de contenido de Bardin (1977). El resultado de nuestra investigación apunta a la existencia de lagunas relacionadas con los conceptos básicos de sonido, ya que este tema es poco abordado en las habilidades bien ofrecidas, y cuando aparecen, no se discuten. Las conclusiones de este estudio revelan que cuando se invita a los profesores a realizar investigaciones, éstos son capaces de realizar análisis en un contexto dotado de significados. De esta forma, los docentes se vuelven capaces de utilizar conceptos científicos como instrumentos de lectura, comprensión del mundo y significado.

Palabras clave: Enseñanza de las ciencias; Formación de profesores; Acústica.

\section{Introdução}

Ao longo dos anos de experiência na docência dos Anos Iniciais do Ensino Fundamental nasceu uma inquietude em buscar novas metodologias de ensino, com o objetivo de tentar solucionar os desafios de lecionar ciências para crianças; uma vez que as formações continuadas ofertadas na grande maioria das redes municipais de ensino, em geral, estão voltadas para as disciplinas de Língua Portuguesa e Matemática. Essa constatação, despertou em nós, a consciência de que a área de ciência também necessita de um olhar crítico no sentido de analisarmos e aprimorarmos nosso conhecimento em relação às diversas propostas presentes na Base Nacional Comum Curricular (BNCC) para os Anos Iniciais do Ensino Fundamental (AIEF).

Nossa experiência docente nos impulsiona a direcionar temas importantes para a formação básica em ciência e tecnologia no intuito de desenvolver conteúdos que nem sempre tem merecido maior atenção. Dada a relevância dessas abordagens, pretende-se trabalhar com professores dos Anos Iniciais temas imprescindíveis à vivência cotidiana da tecnologia e do desenvolvimento científico.

Esta sequência didática investigativa sobre conceitos básicos relacionados ao Som, segue os passos do ensino de ciências por investigação, proposto por Carvalho (1988) e foi elaborada para professores que lecionam nos AIEF, mais especificamente no terceiro ano. A autora acima mencionada vem se destacando na literatura com suas diversas obras no ensino de ciências por investigação, evidenciando a importância do saber docente e a maneira em que o educador o aplicará em suas aulas instigando os alunos a obter novas descobertas sobre os fenômenos físicos e da natureza que estão ao nosso redor agregando conhecimento acerca do mundo em que vivem. No entanto, para que as crianças consigam chegar a esses conhecimentos, o professor precisa buscar subsídios para aplicar este processo de ensino aprendizagem seguindo as etapas de preparação, construção e manipulação do recurso de ensino, dentro dos respectivos referenciais teóricos.

Ao concentrarmos este delineamento com professores dos AIEF, buscamos eleger um tema muito importante na Ciência atual: os conceitos básicos sobre o Som envolvendo seu universo conceitual. Isto posto, ressaltando que direcionamos nosso estudo para a construção do conhecimento científico dos docentes participantes. 
Research, Society and Development, v. 11, n. 1, e32611124848, 2022

(CC BY 4.0) | ISSN 2525-3409 | DOI: http://dx.doi.org/10.33448/rsd-v11i1.24848

Diante de um assunto da ciência física, tão valoroso como o estudo do Som, sentimo-nos gratificados quando o mesmo foi incorporado à BNCC e também vigente pelo Currículo da Rede Estadual Paranaense (CREP). No universo em que nos encontramos, mergulhados no avanço da Ciência e da Tecnologia, o Som é parte integrante dessa tecnologia juntamente com a Acústica e a Ondulatória. Se nossas crianças estão inseridas nas tecnologias fazendo uso constante de sons e imagens, a escola deve oportunizar a exploração da formação conceitualmente científica no início do ensino fundamental, buscando encorajar os estudantes a agir sobre os objetos com o intuito de testar suas hipóteses e resolver o problema proposto.

Entendemos que é imprescindível o preparo do docente dos Anos Iniciais para ministrar este tema em sala, tendo em vista que poucos tiveram a oportunidade de se aperfeiçoar em um assunto considerado bastante complexo. Valorizamos muito a Formação Continuada como forma de contínua qualificação docente, a qual busca aperfeiçoar e aprimorar conhecimentos, metodologias e criatividade a fim de melhor contribuir na formação de seus alunos.

Na sequência proposta, abordamos os conceitos básicos sobre o Som como: tipos de ondas, principais ondas presentes em nosso cotidiano, características das ondas mecânicas, eletromagnéticas, transversal, longitudinal e suas formas de propagação. Todos, extremamente essenciais, presentes nos meios de comunicação, inclusive nos diferentes suportes tecnológicos atuais, cuja observação se dará de forma exploratória, investigativa e contextualizada.

Partindo desse pressuposto, verificamos que a pesquisa teve sua origem diante do seguinte problema: Quais as contribuições de uma formação continuada, planejada sob o viés do referencial teórico do ensino de ciências por investigação, na promoção do domínio de conceitos relacionados ao tema "Som", em professores dos AIEF?

Buscando soluções para responder a essa questão, primeiramente aplicamos uma sequência didática intitulada como “O que é o som?” aos professores que lecionam nos terceiros anos do ensino fundamental, na cidade de Mandaguari - PR. A partir desse momento, acompanhamos as etapas dessa investigação, coletamos dados, os quais aqui apresentados nos confirmam que os docentes dos AIEF, quando estimulados a explorar os conteúdos de ciências com base em investigações, começam a desenvolver habilidades que lhes auxiliam construir evoluções conceituais e dominar a linguagem da ciência, tornando-a um instrumento de interpretação e significação do mundo.

A sequência didática apresentada além de investigar os conceitos básicos relacionados ao Som, propõe uma formação continuada aos professores dos $\mathrm{AIEF}$, desenvolvida em EaD, cuja abordagem acontece com textos, questionários, vídeos, experimentos e simuladores para potencializar a aprendizagem dos profissionais envolvidos.

\section{O Ensino de Ciências como Disciplina Escolar}

A disciplina de Ciências nos Anos Iniciais do Ensino Fundamental passou por significativas mudanças com a estruturação da BNCC as quais precisamos enquanto docentes compreender, assim como os objetivos específicos a cada área de ensino. Inclusive, a área de Ciências da Natureza se subdivide em três unidades temáticas: Matéria e Energia, Vida e Evolução, Terra e Universo.

Conforme o próprio documento, cada uma das competências da BNCC é a união de conhecimentos (caracterizados por conceitos e procedimento), habilidades (caracterizadas por práticas, tanto cognitivas quanto socioemocionais), atitudes e valores, com o objetivo de solucionar questões complexas da vida, da cidadania e do trabalho (Brasil, 2017, p. 8).

Ainda no mesmo documento precisamos memorar que as competências são a integração de um conjunto de habilidades, conhecimentos e atitudes. Neste sentido, o conhecimento é aquilo que se sabe, as habilidades exprimem a capacidade de saber fazer e as atitudes dizem respeito ao querer fazer e estão diretamente ligadas à ação.

Há pouco tempo, a Secretaria Estadual de Educação e Esporte (SEED), juntamente com as Secretarias Municipais de Educação de todo o estado, lançaram a versão definitiva do Currículo da Rede Estadual Paranaense (CREP). Vale ressaltar a 
não obrigatoriedade do documento em ser utilizada pelas redes municipais e particulares de ensino do Estado. Porém, caso a rede municipal de educação e escolas privadas tenham interesse em utilizá-lo na integralidade ou em partes, a Secretaria entende esse interesse como fortalecimento curricular do Estado do Paraná (Seed, 2020).

O CREP complementa o já aprovado Referencial Curricular do Paraná: princípios, direitos e orientações, trazendo conteúdos essenciais para cada componente curricular (coluna conteúdos), em cada ano do Ensino Fundamental, e, também, sugestões de distribuição temporal dos conteúdos nos trimestres ao longo do ano (Seed, 2020).

Segundo o exposto no ano de 2019, a versão preliminar do CREP passou por um processo de consulta pública, recebendo ajustes e contribuições da comunidade escolar. No decorrer do ano de 2020, ele passou a ser o documento orientador da construção de Proposta Pedagógica Curricular (PPP), em especial na construção e elaboração dos Planos de Trabalho Docente e Planos de Aula dos docentes da Rede da rede Municipal de Ensino de Mandaguari/Pr.

Diante dessa realidade a Secretaria Municipal de Educação de Mandaguari, aderiu ao CREP em sua rede de Ensino, sendo o documento norteador das práticas pedagógicas no município. Entretanto, inúmeras incertezas relacionadas à Unidade Temática Matéria e Energia ocorrem entre os docentes que lecionam nos terceiros anos da Rede Municipal.

Veja como o CREP apresenta uma aula de Ciências para alunos do terceiro ano dos Anos Iniciais do Ensino Fundamental abordando a unidade temática Matéria e Energia, conforme o Quadro 1. Esta instrução possibilita ao professor obter meios de transformar a curiosidade sobre o ensino do Som e Acústica e ao mesmo tempo gerar conhecimento.

Quadro 1: Ensino de Acústica e som: Sugestão apresentada no CREP

\begin{tabular}{|c|c|c|c|c|}
\hline $\begin{array}{l}\text { UNIDADES } \\
\text { TEMÁTICAS }\end{array}$ & $\begin{array}{c}\text { OBJETOS DE } \\
\text { CONHECIMENTO }\end{array}$ & OBJETIVOS DE APRENDIZAGEM & CONTEÚDO(S) & TRIMESTRE \\
\hline \multirow{5}{*}{ Matéria e energia } & \multirow{3}{*}{ Produção de som } & \multirow{3}{*}{$\begin{array}{l}\text { Produzir diferentes sons a partir da vibração de } \\
\text { variados objetos e identificar variáveis (forma } \\
\text { do objeto, tamanho, material do que é feito } \\
\text { etc.) que influem nesse fenômeno. }\end{array}$} & $\begin{array}{l}\text { Produção do som em } \\
\text { diferentes objetos. }\end{array}$ & \multirow{3}{*}{$3^{\circ}$} \\
\hline & & & $\begin{array}{c}\text { Som natural e som } \\
\text { produzido pelo ser } \\
\text { humano. }\end{array}$ & \\
\hline & & & $\begin{array}{l}\text { Percepção do som pelo ser } \\
\text { humano. }\end{array}$ & \\
\hline & \multirow[t]{2}{*}{ Saúde auditiva e visual } & \multirow{2}{*}{$\begin{array}{l}\text { Discutir hábitos necessários para a manutenção } \\
\text { da saúde auditiva e visual considerando as } \\
\text { condições do ambiente em termos de som e } \\
\text { luz. }\end{array}$} & $\begin{array}{l}\text { Hábitos saudáveis } \\
\text { relacionados à prevenção e } \\
\text { manutenção da saúde } \\
\text { auditiva e visual, } \\
\text { individual e coletiva. }\end{array}$ & \multirow[t]{2}{*}{$3^{\circ}$} \\
\hline & & & $\begin{array}{l}\text { Poluição sonora e Poluição } \\
\text { visual } \\
\text { Benefícios e perigos da } \\
\text { exposição solar. }\end{array}$ & \\
\hline
\end{tabular}

Fonte: Currículo da Rede Estadual Paranaense, SEED (2020)

Ao analisarmos o quadro acima se faz necessário refletir e oportunizar aos docentes das Redes Municipais de Ensino uma formação continuada capaz de abranger conhecimentos físicos relacionados ao som de modo a expor conceitos que auxiliem o estudante a apropriar-se de conceitos para refletir de forma autônoma sobre eles. Assim sendo, é fundamental que o docente tome consciência da importância da sua ação durante o processo de ensino aprendizagem, pois a função do docente é direcionar seus alunos à construção do conhecimento, tendo em vista as dificuldades dos discentes apresentadas durante o percurso.

Mediante tantas indagações com foco nos conceitos básicos relacionados ao Som, propõe-se uma investigação enfatizada na busca de resolução dos problemas e questões também voltados à exploração teórica entre docentes dos AIEF, aos quais lhes são colocadas situações investigadas por meio de recursos midiáticos de ensino oferecidos. 
Com desafios gerados com os avanços da COVID-19, as escolas passaram por significativas mudanças, os professores precisaram aprender a trabalhar com o ensino remoto em um curto espaço de tempo, pois os estudantes que frequentavam diariamente os bancos escolares passaram a utilizar os computadores como aliados no processo de ensino aprendizagem.

Os professores se permitiram conhecer novas ferramentas, pois os computadores podem ser utilizados de diferentes maneiras no ensino: jogos, simulação, multimídia, softwares, permitindo "a implementação do ciclo descrição-execuçãoreflexão-depuração-descrição, criando as condições para o aluno construir o conhecimento e, portanto, aprender" (Valente, 1995, p. 47). O mesmo autor ainda aborda que:

Os computadores devem estar inseridos em ambientes de aprendizagem, que possibilitam a construção de conceitos e o desenvolvimento de habilidades necessárias para a sobrevivência na sociedade do conhecimento. O aprendizado de um determinado conceito deve ser construído pelo aluno através do desenvolvimento de projetos em que o computador é usado como fonte de informação e recurso para resolução de problemas significativos para o aluno (Valente,1995, p. 47).

Dessa forma, buscamos estabelecer através de uma Sequência Didática Investigativa (SDI), ofertada na modalidade Ead, explorar as relações entre o que produzem no ambiente virtual e como reagem à sua ação (sobre os objetos propostos) e posteriormente, oportunizando aos docentes os recursos disponíveis para auxiliar na aprendizagem.

\section{A Área de Ciências da Natureza e a Formação Docente nos Anos Iniciais do Ensino Fundamental}

Os avanços tecnológicos bem como a influência dos processos relacionados à globalização, motivam diretamente em como realizar as práticas educativas evidenciando as reformulações existentes no currículo escolar. A escola vem buscando acompanhar toda essa realidade, uma vez que o acesso às informações dos estudantes no ambiente externo, consegue muitas vezes superar até mesmo a de seus educadores, especialmente quando nos referimos ao acesso às ferramentas tecnologicamente mais modernas. Neste cenário, precisamos refletir e realizar discussões pautadas na importância do Ensino de Ciências nesse novo cenário educacional. Assim, consentimos com Chassot (2003, p. 22), quando ele nos convida a refletir para o fato de que "se antes o sentido era da escola para a comunidade, hoje é o mundo exterior que invade a escola. Assim, a escola pode não ter mudado; entretanto, pode-se afirmar que ela foi mudada”.

Nesse aspecto, os professores precisam buscar a apropriação do conhecimento científico sendo capazes de tomar decisões sobre diversos assuntos do mundo exterior como medicamentos, alimentos, combustíveis, transportes, comunicações, contracepções, saneamento entre muitos outros temas. "Isso por si só já justifica, na educação formal, a presença da área de Ciências da Natureza, e de seu compromisso com a formação integral dos alunos” (Brasil, 2018, p. 319). É muito importante a sociedade se apropriar do Ensino de Ciências não só pelo fato de compreender os conceitos científicos, mas, também, no intuito de despertar o interesse para as carreiras dessa área (Unesco, 2005).

Diante dessa realidade precisamos auxiliar nossos alunos a desenvolver sua argumentação, interagir com a atual realidade, aguçar sua curiosidade de modo a obter êxito no momento da construção e da desconstrução dos seus conhecimentos acerca das Ciências. Dessa forma,

o Ensino de Ciências assume, assim, um papel muito importante. Orienta-se para a promoção da cidadania, com vistas ao desenvolvimento dos sujeitos enquanto cidadãos ativos, consumidores e usuários responsáveis da tecnologia existente (Viecheneski \& Carletto, 2013, p. 213).

Assim, precisamos compreender que nossa missão enquanto docente, vai muito além do que se preocupar em cumprir os conteúdos científicos, nosso olhar deve estar em auxiliar o estudante a desenvolver sua criticidade no meio em que vive 
(Chassot, 2017). Compreendemos também que a aprendizagem na disciplina de Ciências oferece uma ampliação dos sentidos e percepção no que tange às transformações e evoluções que ocorrem na natureza e no mundo.

A escola tem um papel importante nesse processo, visto que ao oportunizar a discussão e exploração do conhecimento científico nas diferentes etapas e modalidades de ensino, estamos oportunizando aos estudantes uma ferramenta altamente poderosa no mundo atual. Isto posto, o documento da UNESCO - Ensino de Ciências: futuro em risco, aborda a seguinte problemática:

Grande parte da população, apesar de viver num mundo modelado pela ciência e tecnologia, se mantém à margem do acesso ao conhecimento científico, que continua a ser praticamente propriedade de uma elite. O conhecimento de uma escassa elite foi capaz de construir as Grandes Navegações, o Renascimento e as primeiras Revoluções Industriais. Hoje a dimensão é outra: numa sociedade tecnificada é preciso que todos tenham acesso ao conhecimento e que muitos tenham capacidade de criá-lo. Esta situação nos conduz à urgência de democratizar as Ciências desde o início da escolarização, para que todos tenham as mesmas possibilidades no mundo da cultura científica (Unesco, 2005, p. 2).

Nesse contexto, compreendemos a importância de promover a alfabetização científica nos AIEF favorecendo não somente a leitura do mundo natural, mas também a compreensão das reais necessidades de transformações da natureza com um olhar analítico para melhorar a vida na Terra. Assim sendo, é possível perceber que as evoluções tecnológicas e científicas são capazes de amparar as pesquisas voltadas para sobrevivência e qualidade de vida, podendo ser altamente nocivas para o bem estar do planeta.

Até mesmo o desenvolvimento da área tecnológica e econômica de um país, está ligado a um Ensino de Ciências mais significativo, conforme podemos perceber no documento da UNESCO (2005, p. 2):

Países que alcançaram desenvolvimento significativo, como Espanha, Irlanda, Japão, Coréia e outros países asiáticos, são prova disso. Todos efetuaram massivos investimentos em educação, especialmente no Ensino de Ciências, o que se refletiu diretamente no desenvolvimento científico e tecnológico. Não foi por acaso que ocorreu o chamado "milagre asiático".

Para que esses objetivos sejam atingidos o professor terá um papel de extrema importância, uma vez que a sala de aula deve oportunizar um espaço de interação entre responsáveis, professores e alunos. Cabe ao docente a tarefa de garantir o acesso ao conhecimento científico dos estudantes, aspirando às novas aquisições passando de meros espectadores a protagonistas no processo de ensino aprendizagem. Contudo, para que esse processo ocorra, é indispensável que o professor desenvolva e aprimore constantemente um conjunto de habilidades para conseguir planejar, organizar, e ministrar as suas aulas. Nesse sentido a formação continuada do docente colabora de forma construtiva em seu processo de ensino aprendizagem.

As pesquisas com foco na formação de professores avançam significativamente no universo acadêmico, contudo, evidenciamos a pesquisa desenvolvida com professores de Ciências pelos pesquisadores Magalhães Júnior e Pietro Cola (2011, p. 187) que averiguaram que os professores participantes da pesquisa, mesmo praticando um ensino fragmentado, “conseguem contextualizar as Ciências naturais no dia-a-dia de seus alunos". Os autores constataram a necessidade de romper com as estruturas tradicionais de ensino. Em razão disto, é evidente a necessidade de as redes municipais de ensino investirem em uma formação continuada que não seja somente no início e no meio do ano letivo, mas no decorrer do ano letivo, que oportunize ao docente encontros mensais, bimestrais ou trimestrais.

Quando refletimos na formação inicial de professores disponibilizada a alguns anos atrás, podemos afirmar que era considerada como sendo suficiente, essa ideia perdurou durante muitos anos, uma vez que os conhecimentos assimilados no período da graduação eram considerados satisfatórios para permitir o seu exercício profissional, todavia essa realidade sofreu 
significativas mudanças. Couto (2005, p.14) enfatiza: "O professor é o elemento chave para dar corpo às reformas na escola, as quais têm como principal meta preparar cidadãos aptos para conviver e trabalhar com a complexidade do cotidiano". Isto posto, o docente em seu fazer pedagógico, constantemente vem se deparando com situações que lhe causam insegurança com relação ao conteúdo que será ministrado surgindo questionamentos que podem aparecer oriundos dessas informações.

Portanto, se faz necessário oportunizar ao docente caminhos através da formação continuada com referenciais teóricos e metodológicos fundamentado em uma proposta que favoreça a análise da ação docente bem como garanta que os conhecimentos científicos, de fato, possam acontecer em sala de aula.

\section{O estudo sobre o Som nos Documentos de Ensino de Ciências da Natureza}

Em nossa vida cotidiana estamos em contato com os fenômenos relacionados à ondulatória, podemos facilmente listar uma enorme diversidade de aparelhos e fenômenos ligados ao estudo das ondas. Estamos inseridos em um mundo tecnológicos que diariamente afetam nossa rotina e da sociedade, que derivam, em grande parte dos processos relacionados as pesquisas desenvolvidas em Ciências, ampliando o nosso acervo de ferramentas domésticas, profissionais, pessoais e até mesmo, afetivas.

O nosso primeiro contato com os fenômenos relacionados à ondulatória, segundo Brito (2003, p. 35), tem início dentro do ventre materno, conseguimos ouvir os sons emitidos pelo corpo da nossa mãe, desde a sua voz até a sua respiração. Depois do parto o envolvimento com os sons é permanente, embora não tenhamos o conhecimento sobre o que está ocorrendo em nosso meio, as ondas sonoras estão presentes em nossa vida.

Antes mesmo de iniciar sua vida escolar, já são oportunizadas às crianças contato com os meios tecnológicos consequentemente com fenômenos relacionados ao som. "Assim, ao iniciar o Ensino Fundamental, os alunos possuem vivências, saberes, interesses e curiosidades sobre o mundo natural e tecnológico que devem ser valorizados e mobilizados. Esse deve ser o ponto de partida de atividades que assegurem a eles construir conhecimentos sistematizados de Ciências, oferecendo--lhes elementos para que compreendam desde fenômenos de seu ambiente imediato até temáticas mais amplas" (Bncc, 2017 p.331).

Diante disso, ao iniciar sua vida escolar, as crianças necessitam terem o contato com a disciplina de Ciência. Conforme salienta a BNCC:

Ao estudar Ciências, as pessoas aprendem a respeito de si mesmas, da diversidade e dos processos de evolução e manutenção da vida, do mundo material - com os seus recursos naturais, suas transformações e fontes de energia -, do nosso planeta no Sistema Solar e no Universo e da aplicação dos conhecimentos científicos nas várias esferas da vida humana. Essas aprendizagens, entre outras, possibilitam que os alunos compreendam, expliquem e intervenham no mundo em que vivem (Bncc, 2017 p.325).

Em nosso estado, os conteúdos são estruturados pelo CREP, um documento construído em parceira com as redes municipais de ensino" "O CREP complementa o já aprovado Referencial Curricular do Paraná: princípios, direitos e orientações, trazendo os conteúdos para cada componente curricular em cada ano do Ensino Fundamental” (Crep, 2021). Vale ressaltar que nenhuma rede municipal de ensino tem a obrigatoriedade te implantação, no caso da rede municipal de Educação de Mandaguari, esse documento é implantado em toda as escolas da rede municipal de Ensino. Assim sendo, podemos perceber que os fenômenos relacionados ao Som, são contemplados não somente na disciplina de Ciências, como também na

\footnotetext{
${ }^{1}$ As redes municipais de ensino não são obrigadas a seguirem o referido documento. No município de Mandaguari/Pr onde se realizou a pesquisa o CREP é adotado pela rede municipal.
} 
disciplina de Arte e Educação Física, conforme podemos observar no Quadro 2, onde realizamos um levantamos dos conteúdos relacionados ao Som nas disciplinas de Arte, Ciências e Educação Física para os primeiros anos dos AIEF.

Quadro 2: Conteúdos relacionados ao som, apresentados pelo CREP para o primeiro ano do AIEF.

\begin{tabular}{|c|c|c|c|c|c|}
\hline TURMA & DISCIPLINA & $\begin{array}{l}\text { UNIDADE } \\
\text { TEMÁTICA }\end{array}$ & $\begin{array}{c}\text { OBJETOS DE } \\
\text { CONHECIMENTO }\end{array}$ & CONTEÚDO & TRIMESTRE \\
\hline \multirow{8}{*}{ 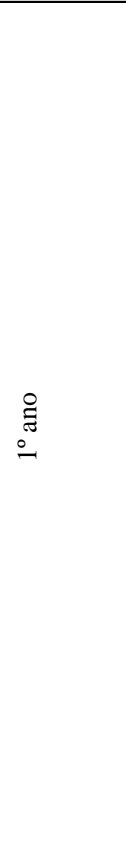 } & \multirow{6}{*}{ 娄 } & \multirow{6}{*}{ 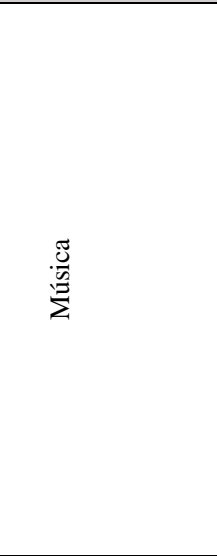 } & Elementos da linguagem & $\begin{array}{c}\text { Parâmetros sonoros (altura, } \\
\text { duração, timbre e intensidade). }\end{array}$ & \multirow[t]{4}{*}{$1^{\circ}$} \\
\hline & & & \multirow[t]{3}{*}{ Materialidades } & $\begin{array}{l}\text { Exploração de fontes sonoras. } \\
\text { Reconhecimento dos elementos } \\
\text { constitutivos da música e as } \\
\text { características de instrumentos } \\
\text { musicais variados }\end{array}$ & \\
\hline & & & & $\begin{array}{c}\text { Gêneros musicais variados } \\
\text { existente no repertório musical } \\
\text { brasileiro. }\end{array}$ & \\
\hline & & & & $\begin{array}{l}\text { Pesquisa de sons e confecção de } \\
\text { objetos sonoros. }\end{array}$ & \\
\hline & & & Processos de criação & $\begin{array}{c}\text { Improvisos de sonorização em } \\
\text { histórias infantis entre outros de } \\
\text { modo individual, coletivo e } \\
\text { colaborativo. }\end{array}$ & $2^{\circ}$ \\
\hline & & & Contextos e práticas & Gêneros musicais brasileiro. & $3^{\circ}$ \\
\hline & 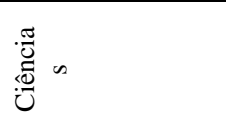 & 每 & Corpo humano & $\begin{array}{l}\text { Órgãos dos sentidos, localizações, } \\
\text { estímulos e funçôes. }\end{array}$ & $1^{\circ}$ \\
\hline & 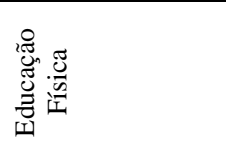 & 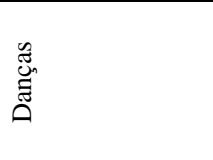 & $\begin{array}{l}\text { Brincadeiras cantadas e } \\
\text { cantigas de roda }\end{array}$ & $\begin{array}{l}\text { Gato e rato, Adoletá, Capelinha de } \\
\text { melão, Caranguejo, Atirei o pau no } \\
\text { gato, Ciranda cirandinha, Escravos } \\
\text { de Jó, Lenço atrás, Dança da } \\
\text { cadeira, entre outras. }\end{array}$ & $3^{\circ}$ \\
\hline
\end{tabular}

Fonte: Currículo da Rede Paranaense de Ensino. (Crep, 2020)

Podemos analisar que os fenômenos relacionados às ondas sonoras estão presentes logo no primeiro ano de escolarização, onde se faz necessário que os docentes compreendam e explorem cientificamente os conceitos relacionados à altura, duração, ao timbre e à intensidade, evidenciando que a responsabilidade de se trabalhar com os fenômenos relacionados ao Som, não está somente a cargo do professor de Ciências.

No Quadro 3 apresentamos os conteúdos relacionados ao Som nas disciplinas de Arte, Ciências e Educação Física para o segundo ano do AIEF.

Quadro 3: Conteúdos relacionados ao som, apresentados pelo CREP para o segundo ano do AIEF

\begin{tabular}{|c|c|c|c|c|c|}
\hline TURMA & DISCIPLINA & $\begin{array}{c}\text { UNIDADE } \\
\text { TEMÁTICA }\end{array}$ & $\begin{array}{c}\text { OBJETOS DE } \\
\text { CONHECIMENTO }\end{array}$ & CONTEÚDO & TRIMESTRE \\
\hline \multirow{6}{*}{ 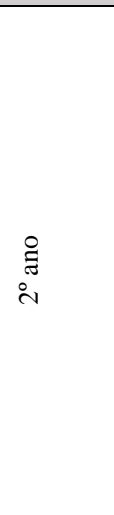 } & \multirow{4}{*}{ 娄 } & \multirow{4}{*}{ 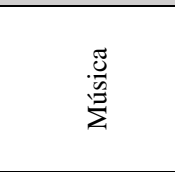 } & \multirow[t]{2}{*}{ Materialidades } & $\begin{array}{l}\text { Gêneros musicais variados existente no repertório musical } \\
\text { brasileiro. }\end{array}$ & $1^{\circ}$ \\
\hline & & & & Pesquisa de sons e confecção de objetos sonoros. & $2^{\circ}$ \\
\hline & & & Elementos da linguagem & Parâmetros sonoros. & $3^{\circ}$ \\
\hline & & & Contextos e práticas & Gêneros musicais brasileiro. & $3^{\circ}$ \\
\hline & 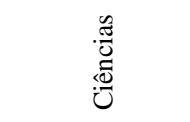 & 苞 & $\begin{array}{l}\text { Cuidados com o corpo } \\
\text { humano }\end{array}$ & Cuidados e respeito com o corpo humano. & $1^{\mathrm{o}}$ \\
\hline & 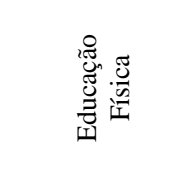 & 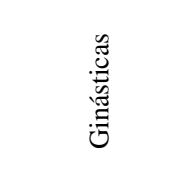 & $\begin{array}{l}\text { Ginástica geral e o } \\
\text { reconhecimento do corpo }\end{array}$ & $\begin{array}{l}\text { Jogos gímnicos, Movimentos gímnicos (balancinha, vela, } \\
\text { rolamentos, paradas, estrela, rodante, ponte) dentre outras; } \\
\text { significado de corpo humano, esquema corporal, segmentos } \\
\text { maiores e menores, órgãos do corpo, percepção sensorial, } \\
\text { percepção motora, entre outras. }\end{array}$ & $3^{\circ}$ \\
\hline
\end{tabular}

Fonte: Currículo da Rede Paranaense de Ensino (Crep, 2020). 
Quando analisamos os conteúdos do segundo ano, podemos perceber que na disciplina de Arte temos o maior enfoque sobre os fenômenos ondulatórios, sendo oferecido no decorrer de todo o ano, na disciplina de Ciências o conteúdo está sendo abordado no primeiro semestre sendo explorados os cuidados e respeito que deveremos ter com o nosso corpo, sendo de grande valia o docente explorar com os estudantes a importância da saúde auditiva. Na disciplina de Educação Física o professor pode explorar e dar enfoque na percepção auditiva dando enfoque a capacidade para receber e interpretar informações que chegam aos ouvidos através das ondas de frequência transmitidas pelo ar ou outros meios, conceitos que os professores devem conhecer.

No Quadro 4, realizamos o levantamento dos conteúdos no terceiro ano das disciplinas de Arte, Ciência e Educação Física.

Quadro 4: Conteúdos relacionados ao som, apresentados pelo CREP para o terceiro ano do AIEF.

\begin{tabular}{|c|c|c|c|c|c|}
\hline TURMA & DISCIPLINA & $\begin{array}{l}\text { UNIDADE } \\
\text { TEMÁTICA }\end{array}$ & $\begin{array}{l}\text { OBJETOS DE } \\
\text { CONHECIMENTO }\end{array}$ & CONTEÚDO & TRIMESTRE \\
\hline \multirow{9}{*}{$\begin{array}{l}\stackrel{\Xi}{\Xi} \\
\text { in }\end{array}$} & \multirow[b]{4}{*}{ 娄 } & \multirow[b]{4}{*}{ 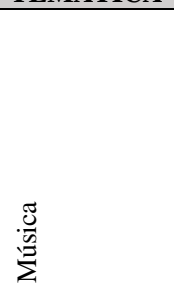 } & \multirow[t]{2}{*}{$\begin{array}{l}\text { Elementos da } \\
\text { Linguagem }\end{array}$} & $\begin{array}{l}\text { Parâmetros sonoros (altura, intensidade, timbre, melodia, } \\
\text { ritmo etc.). }\end{array}$ & $1^{\circ}$ \\
\hline & & & & $\begin{array}{l}\text { Brincadeiras musicais com ritmo: } \\
\text { ternário/valsa, entre outros). }\end{array}$ & $1^{\circ}$ \\
\hline & & & Materialidades & $\begin{array}{l}\text { Cantar músicas e executar jogos e brincadeiras cantadas do } \\
\text { repertório musical brasileiro. }\end{array}$ & $1^{\circ}$ \\
\hline & & & Materialidades & $\begin{array}{l}\text { Exploração de fontes sonoras reconhecimento dos elementos } \\
\text { constitutivos da música e as características de instrumentos } \\
\text { musicais variados. }\end{array}$ & $2^{\circ}$ \\
\hline & \multirow{5}{*}{ 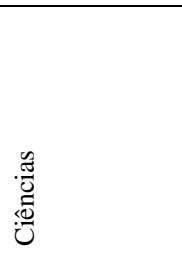 } & \multirow{5}{*}{ 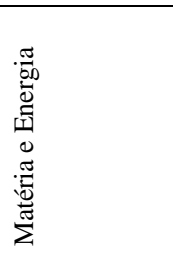 } & \multirow[b]{3}{*}{ Produção de som } & Produção do som em diferentes objetos. & $3^{\circ}$ \\
\hline & & & & Som natural e som produzido pelo ser humano. & $3^{\circ}$ \\
\hline & & & & Percepção do som pelo ser humano. & $3^{\circ}$ \\
\hline & & & \multirow[t]{2}{*}{ Saúde auditiva e visual } & $\begin{array}{l}\text { Hábitos saudáveis relacionados à prevenção e manutenção da } \\
\text { saúde auditiva e visual, individual e coletiva. }\end{array}$ & $3^{\circ}$ \\
\hline & & & & $\begin{array}{l}\text { Poluição sonora e Poluição visual } \\
\text { Benefícios e perigos da exposição solar. }\end{array}$ & $3^{\circ}$ \\
\hline 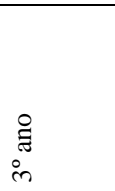 & 胥 & 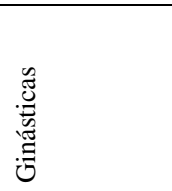 & 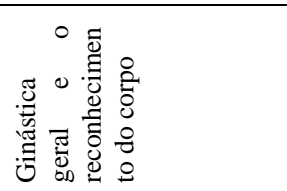 & $\begin{array}{l}\text { Jogos gímnicos, Movimentos gímnicos (balancinha, vela, } \\
\text { rolamentos, paradas, estrela, rodante, ponte) dentre outras; } \\
\text { Significado de corpo humano, esquema corporal, segmentos } \\
\text { maiores e menores, órgãos do corpo, percepção sensorial, } \\
\text { percepção motora, entre outras. }\end{array}$ & $3^{\circ}$ \\
\hline
\end{tabular}

Fonte: Currículo da Rede Paranaense de Ensino (Crep, 2020).

Analisando os conteúdos disponibilizados nos quadros acima, podemos perceber que os fenômenos relacionados ao som, são abordados em Arte, Ciência e Educação Física. Na rede municipal de Educação de Mandaguari, o docente que leciona a disciplina de Arte, também é responsável por ministrar as disciplinas de Língua Portuguesa, Matemática e Ensino Religioso. O docente que é responsável pela disciplina de Ciências, leciona também Geografia e história e o professor de Educação Física é responsável somente por essa disciplina, uma vez que é exigido Licenciatura Plena na disciplina. Desse modo, fica evidente a necessidade de aprimoramento profissional, capacitações, formações continuadas com foco no Ensino de Ciências.

\section{Ensino por Investigação nos Anos Iniciais}

O Ensino de Ciências por investigação vem sendo difundido e merece destaque no ambiente escolar, especialmente quando analisamos os documentos oficiais bem como os passos envolvendo as propostas investigativas, colaboram para o desenvolvimento de novas estruturas didáticas. Como pode ser compreendido, nas descrições de Grandy e Duschl (2007), as propostas com foco no ensino investigativo se apresentam nos currículos por levarem os alunos a desenvolverem e a realizarem explorações acerca do conteúdo a ser trabalhado, proporcionando uma compreensão da construção do que seja a 
investigação científica. Os autores, evidenciam a construção bem como o entendimento acerca das modificações do fazer científico, sendo necessário uma nova percepção da própria ideia de investigação, assim como analisarmos como esse ensino é levado para a sala de aula.

Vale destacar, que a Ciência ministrada em sala de aula deve romper com os moldes tradicionais de ensino, ampliar e privilegiar a construção do conhecimento investindo em propostas investigativas com o propósito de oportunizar aos estudantes condições na resolução de problemas explorando as relações causais entre variáveis para explicar os fenômenos ocorrido durante a observação, possibilitando caminhos para a compreensão conceitual, favorecendo a construção e ideias favorecendo a construção, bem como a elaboração de modelos com sustentação científica.

As propostas com caráter investigativo apresentam-se como "elemento central na formação dos estudantes [...] possibilitando aos alunos revisar de forma reflexiva seus conhecimentos e sua compreensão acerca do mundo em que vivem" (Brasil, 2017, p.318). O conhecimento científico, passa a ser visto como um eixo estruturante no ensino e aprendizagem escolar,

[...] por meio de um olhar articulado de diversos campos do saber, precisa assegurar aos alunos do Ensino Fundamental o acesso à diversidade de conhecimentos científicos produzidos ao longo da história, bem como a aproximação gradativa aos principais processos, práticas e procedimentos da investigação científica (Brasil, 2017, p. $317)$.

Assim sendo, a alfabetização científica ${ }^{2}$ é evidenciada na BNCC como um processo de extrema importância no Ensino de Ciências, "o compromisso com o desenvolvimento do letramento científico, que envolve a capacidade de compreender e interpretar o mundo (natural, social e tecnológico), mas também de transformá-lo com base nos aportes teóricos e processuais das ciências" (Brasil, 2017, p.317).

Embora não tenhamos uma abordagem com foco na historicidade, a BNCC nos anos iniciais do Ensino Fundamental, está pautada na valorização das situações que envolvem a ludicidade, articulando com as experiencias oportunizadas na Educação Infantil. Essa articulação necessita estar entrelaçada com a progressiva sistematização dessas experiencias com o desenvolvimento dos estudantes a novas formas de observar o mundo, as novas possibilidades de leitura e formulação de hipóteses sobre os fenômenos da natureza, estimulando o aprendiz a realizar teste, refutá-las, serem conduzidos a elaborar conclusões proporcionando uma atitude ativa na construção de conhecimentos (Brasil, 2018, p. 55-56). Nesse sentido, os docentes dos Anos Iniciais necessitam explorar os fundamentos epistemológicos do Ensino de Ciências, particularmente os que evidenciados os sentidos humanos e o desenvolvimento dos primeiros sentidos com o mundo: O saber, o fazer e suas relações com o concreto e com o imaginário. Vale destacar a importância do direcionamento pedagógico disponibilizado pelas unidades de ensino, oferecendo suporte e orientação sobre a temática.

Ao iniciar essa nova etapa de ensino os alunos egressos nos anos iniciais do Ensino Fundamental possuem inúmeras vivencias, diversos saberes, interesses e curiosidades envolvendo o mundo natural e tecnológico que devem e precisam ser valorizados, sendo aproveitados como ponto de partida para a construção de conhecimentos sistematizados na disciplina de Ciências, oportunizando elementos para a compreensão de fenômenos que envolvem o seu ambiente imediato até mesmo temáticas mais amplas (Brasil, 2018, p. 329). "Deve-se buscar cada vez mais o entendimento científico pelo entendimento da ação, afastando-se da concepção de Ciência como conhecimento racional, acabado e imutável” (Chassot, 1990, p. 67).

Consentimos com Rosa, Perez e Drum (2007, p. 362), no sentido de que,

\footnotetext{
${ }^{2}$ Quando analisamos a BNCC, esse termo se apresenta com a nomenclatura de Letramento Científico.
} 
ao ensinar ciências às crianças, não devemos nos preocupar com a precisão e a sistematização do conhecimento em níveis da rigorosidade do mundo científico, já que essas crianças evoluirão de modo a reconstruir seus conceitos e significados sobre os fenômenos estudados.

Para promovermos um ensino de ciências eficaz, o docente deve oportunizar momentos em que as crianças consigam evoluir e reconstruir seus conceitos e significados rompendo com os moldes tradicionais de ensino, é preciso oportunizar para nossas crianças um ensino que privilegie a aculturação e não mais a acumulação, auxiliando e orientando a construção do próprio conhecimento, uma vez que ele é parte fundamental do processo de ensino aprendizagem. "Propõe-se a ensinar Ciências a partir do ensino sobre Ciências" (Carvalho et al., 2004, p. 3).

Concordamos com Bizzo (2002, p.14) quando afirma que

O ensino de ciências deve proporcionar a todos os estudantes a oportunidade de desenvolver capacidades que neles despertem a inquietação diante do desconhecido, buscando explicações lógicas e razoáveis, amparadas em elementos tangíveis.

O conhecimento científico é parte fundamental para integração do mundo moderno, os estudantes necessitam serem conduzidos a esse conhecimento, compreendendo a sua importância no processo educativo, bem como o desenvolvimento de funções educativas no contexto escolar.

Os alunos têm, como parte fundamental de sua formação, o conhecimento científico, integrante do mundo moderno, destacando-se como parte essencial de conhecimentos necessários para o desenvolvimento das funções educativas no contexto escolar.

Azevedo (2004, p.22) enfatiza que as aulas investigativas são capazes de estimular o aluno a participar efetivamente do processo de aprendizagem. O aluno inserido em uma aula investigativa é instigado a notar que os conteúdos trabalhos e as discussões ocorridas são essências para a sua vivência no mundo cotidiano.

Utilizar atividades investigativas como ponto de partida para desenvolver a compreensão de conceitos é uma forma de levar o aluno a participar de seu processo de aprendizagem, sair de uma postura passiva e começar a perceber e agir sobre o seu objeto de estudo, relacionando o objeto com acontecimentos e buscando as causas dessa relação, procurando, portanto, uma explicação causal para o resultado de suas ações e/ou interações (Azevedo, 2004 p.22).

Dessa maneira os professores que são responsáveis em lecionar a disciplina de Ciências nos anos iniciais do Ensino Fundamental, dever assumir o papel de mediador no ensino investigativo, buscando promover diferentes estratégias investigativas em sala de aula, uma vez que esse profissional geralmente tem contato com todas as turmas da escola que leciona e cada turma apresenta situações diversas, cabendo a ele realizar as adaptações curriculares necessárias para cada turma se preocupando com as questões conceituais e metodológicas.

\section{Metodologia}

Para realizarmos a presente investigação, nos amparamos nos fundamentos da abordagem qualitativa, por meio da observação participante, sendo submetida à apreciação do comitê Permanente de Ética em Pesquisa com Seres Humanos (COPEP) e aprovada sob o $\mathrm{n}^{\circ}$ 51373021.7.0000.0104, uma vez que essa forma de trabalho “[...] tem por objetivo expressar o sentido dos fenômenos do mundo social" (Neves, 1996, p. 1).

Quanto a modalidade de pesquisa, optamos pelo estudo de caso, dado que "[...] se concentra no estudo de um caso particular, considerado representativo de um conjunto de casos análogos, por ele significativamente representativo" (Severino, 
2007, p. 121). Levando em consideração a presente definição, agimos ativamente nos envolvendo diretamente com os participantes da pesquisa. Esse posicionamento ocorreu com a finalidade de compreender não somente a causa e as consequências do fenômeno investigado, mas também de promover a transformação de uma condição inicial, explorando sob quais bases isso seria possível.

No decorrer de cada etapa do processo de investigação, o pesquisador comportou-se como observador participante. Esse tipo de comportamento [...] "consiste na participação real do pesquisador. Ele se incorpora ao grupo, confunde-se com ele. Fica tão próximo quanto um membro do grupo que está estudando e participa das atividades normais deste” (Marconi \& Lakatos, 2006, p. 90).

Desta forma, comportando-se como pesquisador participante, o investigador da presente pesquisa aplicou a sequência didática investigativa “O que é o som?” com cinco professores que ministram a disciplina de Ciências nos terceiros anos dos Anos Iniciais do Ensino Fundamental, em uma escola da rede Municipal na cidade de Mandaguari - Pr. A escolha dessa escola se justifica pelo fato do pesquisador ser o Supervisor Pedagógico dessa unidade escolar, e ter contato diário com os investigados. Dessa forma, como técnica de coleta de dados, foram utilizados os textos, bem como as falas realizadas em algumas etapas da pesquisa através do aplicativo (Google Meet) e os textos disponibilizados na sala de aula virtual (Google Classrrom).

De posse dos instrumentos de coleta de dados utilizaremos o diário de campo produzido pelo pesquisador, bem como a gravação na integra de todos os relatos dos pesquisados no intuito de obter a maior veracidade daquilo que será dito e/ou discutido durante todo curso de formação, os documentos produzidos pelos participantes durante o referido curso.

\section{Participantes}

Para a seleção dos participantes, primeiramente ocorreu a solicitação, bem como o consentimento da secretária municipal de Educação para realização da pesquisa com a participação de professores que lecionam na disciplina de Ciências na Rede Municipal de Educação de Mandaguari-Pr, evidenciamos que esse é um projeto piloto, os dados apresentados servirão de base para futuras formações continuadas.

Diante das necessidades da utilização de recursos tecnológicos e redes sociais, os mesmos foram convidados de forma privada, no intuito de evitar algum tipo de exposição ou vínculo de dados dos pesquisados nesses canais de comunicação acima mencionado, garantindo a integridade dos seus dados e com isso a veracidade da pesquisa.

Tal convite conteve o link com endereço eletrônico e ainda um texto explicativo com as devidas informações de cada módulo do curso, garantindo ao docente a segurança dos dados apresentados, garantindo o anonimato dos participantes, sendo ainda garantidos o direito de não responder alguma questão, sem a necessidade de maiores esclarecimentos acerca de tal postura, podendo ainda o mesmo retirar-se da pesquisa caso sinta esta necessidade, a qualquer momento.

Os professores pesquisados só terão acesso aos módulos após o seu aceite e/ou consentimento, bem como acesso a todo conteúdo programático da formação continuada.

No início do curso, será explicitado aos professores pesquisados que antes dos mesmos responderem qualquer atividade para efetivação da coleta dos dados, será apresentado o Termo de Concordância, tal documento apresentará todas as informações necessárias para o adequado esclarecimento dos mesmos.

\section{Descrição das atividades}

Organizamos a sequência didática para evidenciando a evolução dos conceitos básicos relacionados ao som para professores de lecionam na rede municipal de Educação de Mandaguari/ Pr na modalidade Ead, a mesma foi desenvolvida em um módulo com e seis etapas. 
A partir da pergunta "O que é som?” estruturamos o módulo e suas respectivas atividades. Procuramos elaborar a sequência didática investigativa SDI de forma que o pesquisador seja capaz de verificar se os professores estão compreendendo os conteúdos de cada módulo, sobretudo, se os objetivos educacionais estão sendo atingidos.

O pesquisador, no decorrer da investigação, agirá como observador participantes. No Quadro 5 apresentados os conteúdos selecionados para este módulo.

Quadro 5: Conteúdo da Sequência didática: “O que é o som?”.

\begin{tabular}{|c|}
\hline Conteúdos da Sequência Didática \\
\hline Introdução à Ondulatória \\
\hline Ondas Mecânicas; \\
Ondas Eletromagnéticas; \\
Ondas Transversais; \\
Ondas Longitudinais \\
Características de uma Onda. \\
\hline
\end{tabular}

Fonte: Elaborado pelos autores.

No Quadro 6 descrevemos a sequência didática bem como as atividades desenvolvidas em cada etapa.

Quadro 6: Sequência didática: “O que é o som?”.

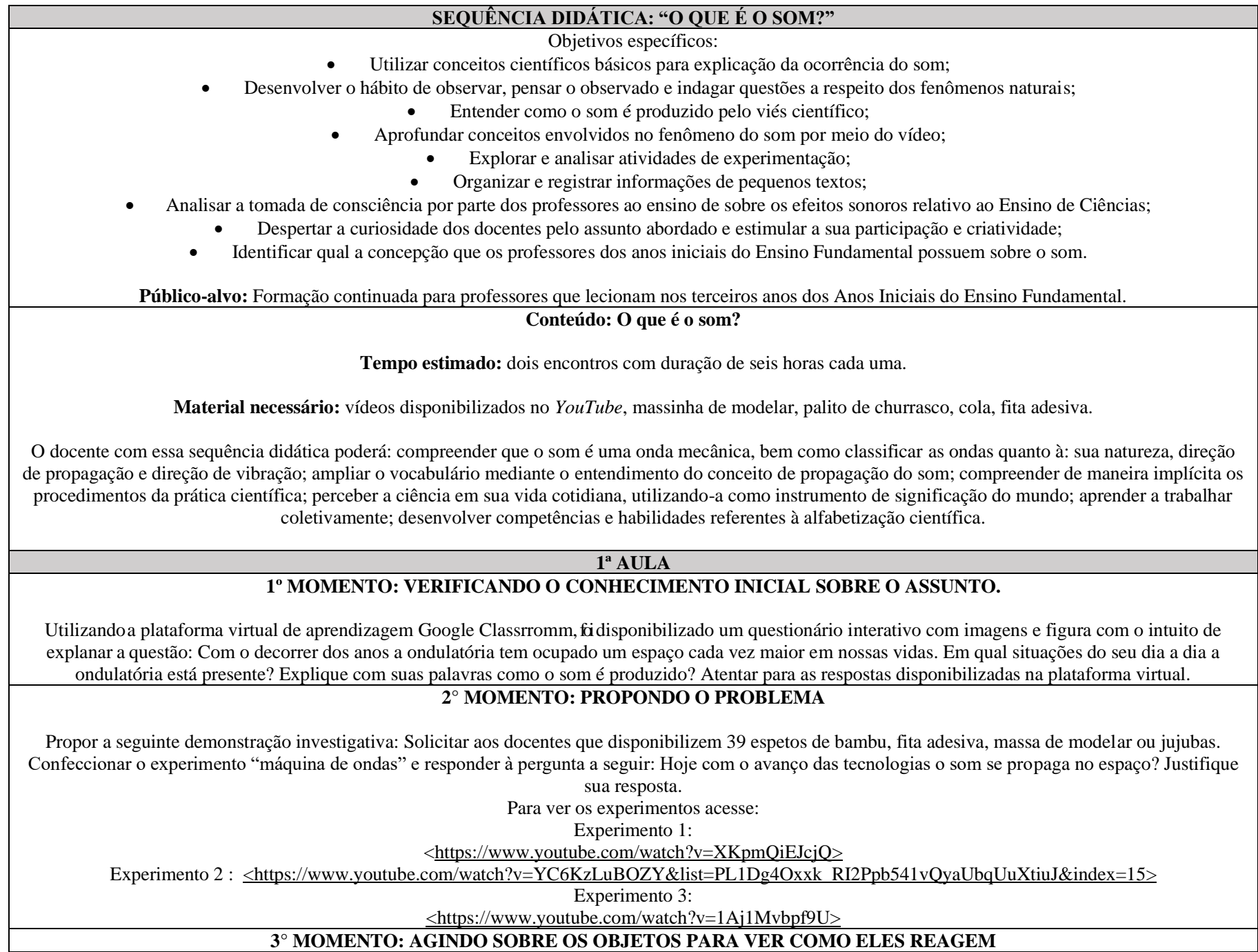


Research, Society and Development, v. 11, n. 1, e32611124848, 2022

(CC BY 4.0) | ISSN 2525-3409 | DOI: http://dx.doi.org/10.33448/rsd-v11i1.24848

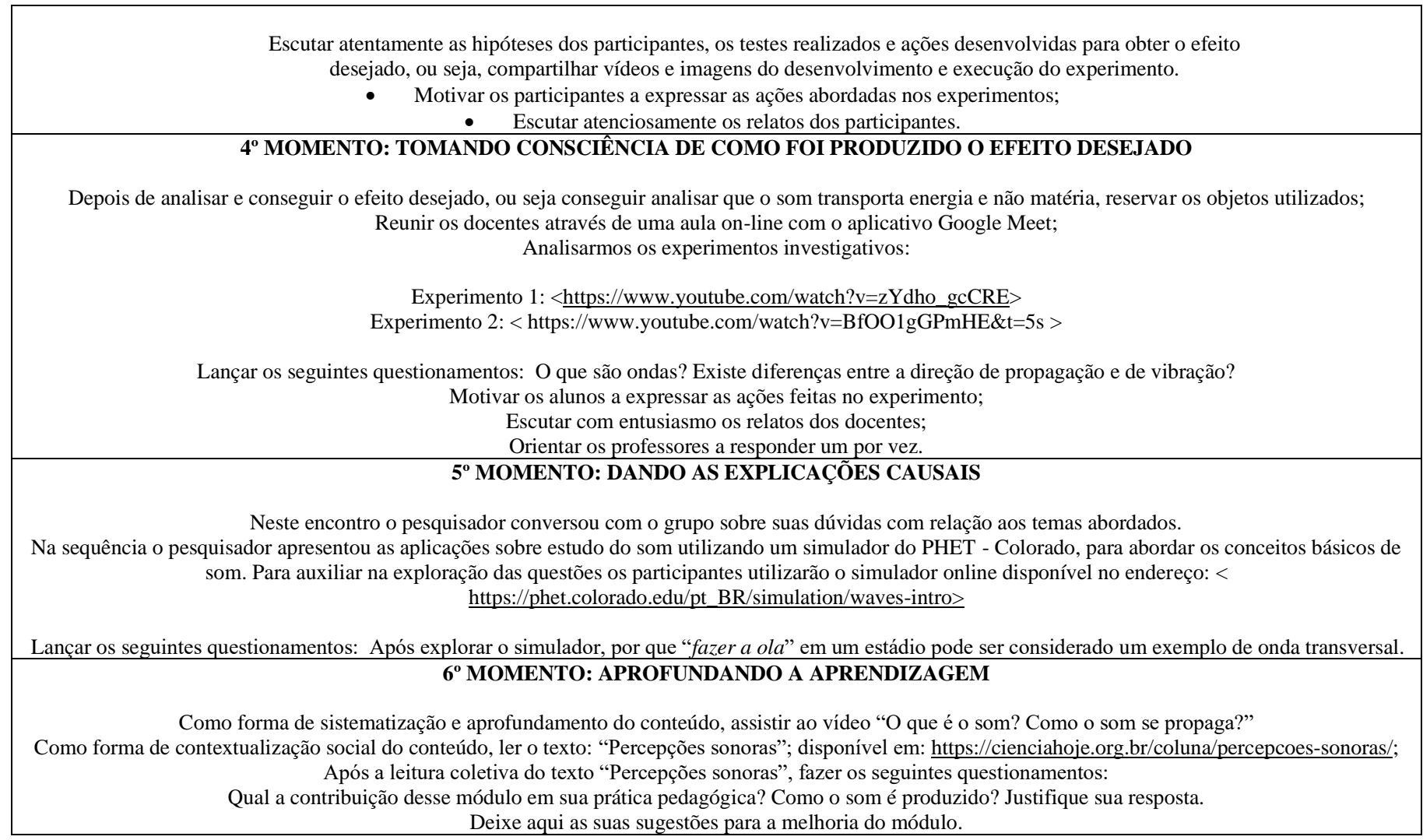

Fonte: Elaborado pelos autores.

Conforme demostrado no Quadro 5, podemos perceber que a sequência foi aplicada em uma etapa, com seis momentos cada uma abordando conteúdos relacionados ao som. Em cada etapa trabalhamos conceitos físicos relacionados ao som, com o intuito de levar os docentes a melhor significação e ressignificação dos conceitos envolvendo a produção do som.

A seguir no Quadro 7, descrevemos quais foram os objetivos de cada momento proposto na sequência didática investigativa "O que é o som?"

Quadro 7: Objetivos de cada momento proposto na sequência didática "O que é o som?".

\begin{tabular}{|c|c|c|c|c|}
\hline MOMENTOS & ETAPAS & CONTEÚDOS & OBJETIVOS & DURAÇÃO \\
\hline $1^{\circ}$ momento & $\begin{array}{c}\text { Verificando o } \\
\text { conhecimento } \\
\text { inicial sobre o assunto. }\end{array}$ & $\begin{array}{l}\text { Características de uma } \\
\text { onda. }\end{array}$ & $\begin{array}{l}\text { Averiguar as ideias prévias que os participantes } \\
\text { possuem sobre o conteúdo. }\end{array}$ & 1 encontro \\
\hline $2^{\circ}$ momento & Propondo o problema. & Ondas mecânicas. & $\begin{array}{c}\text { Analisar o material experimental, e propor a situação } \\
\text { a ser resolvida. }\end{array}$ & 2 encontros \\
\hline $3^{\circ}$ momento & $\begin{array}{l}\text { Agindo sobre os objetos } \\
\text { para ver como eles reagem. }\end{array}$ & $\begin{array}{l}\text { Ondas mecânicas e } \\
\text { eletromagnéticas }\end{array}$ & $\begin{array}{c}\text { Disponibilizar momentos de reflexão para analisar o } \\
\text { problema desenvolvendo hipóteses levando-as ao } \\
\text { teste. }\end{array}$ & 1 encontro \\
\hline $4^{\circ}$ momento & $\begin{array}{l}\text { Tomando consciência de } \\
\text { como foi produzido o } \\
\text { efeito desejado. }\end{array}$ & Ondas mecânicas. & $\begin{array}{l}\text { Estimular o docente a pensar nas ações realizadas, } \\
\text { isto é, romper com as ações manipulativas para ação } \\
\text { intelectual. }\end{array}$ & 1 encontro \\
\hline $5^{\circ}$ momento & Dando explicações causais. & $\begin{array}{l}\text { Ondas transversais e } \\
\text { longitudinais. }\end{array}$ & $\begin{array}{l}\text { Estimular a construção de conceitos, bem como a } \\
\text { ampliação de vocabulário por meio de explicações. }\end{array}$ & 2 encontros \\
\hline $6^{\circ}$ momento & $\begin{array}{l}\text { Aprofundando o } \\
\text { conhecimento. }\end{array}$ & $\begin{array}{l}\text { Característica de uma } \\
\text { onda. }\end{array}$ & $\begin{array}{c}\text { Compreender as } \\
\text { ações e os efeitos causais envolvidos no } \\
\text { experimento com linguagem formal. }\end{array}$ & 2 encontros \\
\hline
\end{tabular}

Fonte: Elaborado pelos autores. 


\section{Análise dos Dados}

Para análise e coleta dos dados, foram embasados nos pressupostos teóricos e metodológicos de Bardin (1977), baseado na Análise de Conteúdo, cujos pesquisadores delimitam alguns parâmetros e categorias, demonstrando todo conhecimento por parte do aprendiz.

Toda essa metodologia de análise consiste em

Uma sequência de técnicas para análise de dados, objetivando por procedimentos sistemáticos e objetivos de toda descrição de conteúdo, e dos resultados obtidos ou seja: (quantitativos ou não), permitindo com isso toda aquisição de conhecimentos destas mensagens (Bardin, 1977, p. 42).

Como instrumentos para análise dos dados coletados, optou-se pela análise do conteúdo. Tendo em vista, que "[...] a intenção da análise de conteúdo é a inferência de conhecimentos relativos às condições de produção [...]” (Bardin, 2011, p. 44), investigando as falas e a escrita dos sujeitos da pesquisa com o objetivo de verificar se os passos bem como as etapas da sequência didática investigativa proporcione aos docentes elementos que indiquem o Ensino por Investigação como uma prática metodológica capaz de promover a aprendizagem de conceitos científicos relacionados ao som.

Para alcançar os objetivos e como estratégia para compreender quais elementos precisariam ser considerados como indicadores na promoção da evolução conceitual dos docentes, nos fundamentamos por meio das leituras exploratórias de Carvalho (2013), Carvalho et al. (1998), Pozo e Crespo (2009) e Campos e Nigro (1999), com base nesses autores, podemos elencar algumas habilidades, que organizamos em categorias. Deste modo, elencamos três categorias: Desconhecimento do conteúdo, Características senso comum de conteúdo, Atributos científico do conteúdo.

Diante do exposto, podemos compreender que a técnica para realizar a análise categorial é considerada como “[...] espécie de gavetas ou rubricas significativas que permitem a classificação dos elementos de significação constitutivos da mensagem” (Bardin,2011, p. 43). Assim, optamos por realizar a separação das categorias levando em consideração os dados coletados evidenciando as unidades de sentido e significação para auxiliar na interpretação dos mesmos.

Isto posto, nos baseamos por essa técnica, sistematizando, através de uma leitura atenta, averiguando na escrita e através da fala dos participantes elementos estruturados nas categorias elencadas. Posteriormente, transcrevemos cuidadosamente as ideias dos pesquisados e realizamos a devida análise.

\section{Resultados e Discussão}

Para a análise dos dados da referida investigação, tomamos como base a sequência didática investigativa "O que é o som?". No primeiro momento com os dados disponíveis no Google Classroom, realizamos a reescrita e a análise do discurso das falas apresentadas no decorrer das aulas, em seguida, realizamos o levantamento de algumas categorias para auxiliar a melhor sintetizar os resultados da presente investigação. Utilizamos a letra "A" acompanhada de números aleatórios para nos referir aos sujeitos pesquisados e o pesquisador utilizamos a letra " $\mathrm{P}$ ".

\section{Análise do Primeiro Momento}

Para darmos início ao nosso curso, alguns pontos merecem destaque. Esse projeto é considerado piloto, uma vez que essa é a primeira formação com foco em Ensino de Ciências por investigação que está sendo ofertado a rede Municipal de Educação de Mandaguari/Pr. Outro ponto que merece destaque está no fato das atividades serem desenvolvidas pelo Google Classroom, e com aulas síncronas pelo Google Meet. Diante do exposto, decidimos auxiliar os docentes a perderem a timidez 
Research, Society and Development, v. 11, n. 1, e32611124848, 2022

(CC BY 4.0) | ISSN 2525-3409 | DOI: http://dx.doi.org/10.33448/rsd-v11i1.24848

se adaptarem com o Google Classroom, iniciamos uma discussão sobre o tema "Quais os desafios em ensinar Ciências hoje", esse momento teve como objetivo verificar como os docentes que estão em sala de aula analisam o Ensino de Ciências.

Nesse momento os docentes começaram a ficar mais familiarizados sentiram-se mais acolhidos, sendo caracterizado o momento por lamentações e reclamações ao invés de um debate sobre o Ensino de Ciências. Suas principais queixas foram marcadas pela atual conjuntura no Ensino causada pela pandemia, alegando a falta de apoio das famílias e o excesso de trabalho que ocasionados pelo Ensino Remoto.

Quando expomos o tema Acústica para discussão, um dos professores já foi logo afirmando:

“Vixi! Em minha formação em pedagogia não foram trabalhados nada sobre esse tema”. (P1)

"Eu sempre tenho dificuldades em abordar esse tema em minhas aulas, me agarro no livro para não errar, se está escrito lá está certo, não busco nada fora, vai que interpreto errado” (P2).

“Só me lembro no Ensino Médio ter visto algo, mas em pedagogia em tocaram no assunto” (P3).

“No meu curso de pedagogia, nem tivemos metodologia de Ensino de Ciências, foi só dado Ciências”.(P4).

“Me formei a pouco tempo, mas não foram trabalhados esses tópicos, nem no meu Ensino Médio, pois sempre faltava professor de Física".(P5).

Essas falas nos demostram sobre a importância da formação continuada nas redes Municipais de Ensino. Nesse caso, como o pesquisador participa ativamente da pesquisa, possivelmente estão tentando justificar suas fragilidades no conteúdo abordado que será detectado no decorrer da formação continuada. Assim, vejamos a transcrição de algumas partes da aula com respectivas análises.

P: Em qual situações do seu dia a dia a ondulatória está presente?

A1: A ondulatória está presente nas transmissões de rádio e TV.

A2: Sinais de wi-fi, ondas de rádio, microondas, tv, luz.

A3: A ondulatória está presente em praticamente todos os momentos do meu dia a dia, seja pelo som ou pela luz.

A3: No estudo de timbres e outros aspectos do som na prática de flauta transversal, para analisar a reverberação no ambiente que vou me apresentar, afinar com outros instrumentos e resolver problemas de interferência e cruzamento de ondas.

A4: ondas sonoras de via rádio, onda do mar.

A5: Ao tocar instrumentos, ouvir música, barulhos internos e externos de casa.

Após esse primeiro momento, podemos utilizar nossas categorias de análise para realizar a interpretação dos resultados as quais se desdobraram em duas subcategorias. A seguir, apresentamos o quadro 8, com todas as 2 categorias elencadas e suas 4 subcategorias emergentes das respostas da primeira pergunta. 
Quadro 8: Categorias, Subcategorias das respostas dos docentes.

\begin{tabular}{|c|c|c|c|c|c|}
\hline \multirow[b]{2}{*}{ Categorias de análise } & \multirow{2}{*}{$\begin{array}{l}\text { Categorias de análise } \\
\text { (Quanto a natureza) }\end{array}$} & \multicolumn{4}{|c|}{ Subcategorias - Tipos de ondas } \\
\hline & & $\begin{array}{c}\text { Ondas } \\
\text { sonoras }\end{array}$ & $\begin{array}{l}\text { Ondas em uma } \\
\text { corda. }\end{array}$ & Ondas de rádio & Onda luz \\
\hline \multicolumn{6}{|l|}{$\begin{array}{c}\text { Desconhecimento do } \\
\text { conteúdo }\end{array}$} \\
\hline \multirow{2}{*}{$\begin{array}{l}\text { Características senso } \\
\text { comum do conteúdo }\end{array}$} & Ondas Mecânicas & $\mathrm{A} 3, \mathrm{~A} 5$ & A5 & $\mathrm{A} 1, \mathrm{~A} 2, \mathrm{~A} 4$ & \\
\hline & Ondas Eletromagnética & & & $\mathrm{A} 2, \mathrm{~A} 4$ & A2, A5 \\
\hline $\begin{array}{c}\text { Atributos científico do } \\
\text { conteúdo. }\end{array}$ & & & & & \\
\hline
\end{tabular}

Fonte: Dados da pesquisa.

Os dados do Quadro 8, nos permite constatar que as respostas dos docentes se alicerçaram no senso comum, compreendemos que não podemos julgar esses e considerar esses conhecimentos errôneos, contudo fica evidente que estão distantes de um conhecimento curricular. Assim podemos perceber que os referidos conhecimentos não foram abordados na formação inicial.

Após esse primeiro momento, questionamos com a segunda pergunta desse primeiro momento "Explique com suas palavras. O que é o som? Foram apresentadas as seguintes falas:

\section{A1: Eu acho que são vibrações e pressão do ar que está a nossa volta. (Acho que é isso!)}

A2: Hum!!!, pode ser uma de propagação de ondas?

A3: É movimentação ondulatória constante da matéria. (é o que eu acho)

A4: O som são vibrações transmitidas somente com uso de objetos. (é o que falaria para meu aluno. Rs!)

A5: Pra mim o som ocorre somente entre objetos vibrantes, e se propagam também nas cordas vocais. (Certo?)

Pelos relatos acima, fica explícita a ideia dos docentes sobre o tema abordado. Embora percebam as situações diárias que envolvem questões relacionadas ao som, quando questionados como o som é produzido podemos perceber "confusões em suas definições". Para analisarmos essas respostas podemos analisar as reflexões de Donald Schon que discute sobre o pensar o que se faz enquanto se está fazendo, ele considera essa ação com reflexão na ação. "É impossível aprender sem ficar confuso" (Schon, 1991, p.85). Dessa forma podemos destacar os conflitos cognitivos apresentados pelos docentes durante a realização das atividades que, de acordo com Schon, essa etapa é de extrema importância para que a aprendizagem ocorra. A seguir, apresentamos o quadro 9, com as 3 categorias elencadas e suas 2 subcategorias emergentes das respostas da segunda pergunta.

Quadro 9: Categorias, Subcategorias das respostas dos docentes.

\begin{tabular}{|c|c|c|}
\hline Categorias de análise & \multicolumn{2}{|c|}{ Subcategorias } \\
\cline { 2 - 3 } & \multicolumn{2}{|c|}{ Vibrações } \\
\hline Desconhecimento do conteúdo & A4 & Aropagações \\
\hline Características senso comum do conteúdo & A4 & \\
\hline Atributos científico do conteúdo. & & A2, A3, A5 \\
\hline
\end{tabular}

Fonte: Dados da pesquisa.

Os dados disponíveis no quadro 9, fica evidente que os conhecimentos dos docentes sobre o assunto abordado estão pautados no senso comum e dois docentes demonstram desconhecimento do assunto, fato este que se justifica por serem professores pedagogos e os conteúdos relacionados ao som, não foram abordados em sua formação inicial. Quando refletimos 
sobre as respostas embasadas no senso comum, sabemos que não podemos considerar esses conhecimentos como errado, todavia estão longe de serem vistos como saberes curriculares.

\section{Análise do Segundo Momento}

Neste momento apresentamos a atividade experimental, todos os materiais necessários para a realização do experimento foram oferecidos aos docentes. Vale ressaltar a importância do problema não ser uma questão qualquer. Ele deve ser interessante, de modo que estimule o aluno a se aventurar em uma investigação, colocando em prática ações e raciocínios necessários ao desenvolvimento intelectual (Carvalho, 2013). Segue os trechos desse momento:

P: Nesse momento, vamos realizar nossa atividade prática, juntos vamos construir um experimento: "A máquina de ondas"

P: Vamos assistir um vídeo com as explicações necessárias para montagem. Prestem a atenção! O que acharam da proposta?

A1: Achei bem bacana, pois todos esses matérias temos na escola, podemos montar tranquilamente com os alunos.

A2: Eu estou empolgada, quero montar.

A3: Será que funciona mesmo?

A4: Não imagina que algo tão simples, pudesse me fazer refletir o quanto aprender com experimento é mais interessante. Quero usar mais em minhas aulas.

A5: Só de assistir, já fiquei com vontade montar ter pra mim essa máquina de ondas, seria tão bom termos vários experimentos nossos para usar sempre em sala de aula. Estou empolgada!

P: Fico muito feliz com a empolgação e disposição de vocês em aprender. Então gostaria de ouvi-las: Hoje com o avanço das tecnologias o som se propaga no espaço?

Após assistirem ao vídeo realizamos a montagem do experimento. Foram apresentadas as seguintes falas:

A1: Sim, o som sempre precisa de um espaço de propagação e o espaço ainda continua sendo um deles.

P: No espaço não existe o vácuo?

A1: Sempre tive curiosidade e até mesmo vergonha em perguntar. Mas como estou bem á vontade com esse grupo, vou perguntar: - O que é vácuo? (Não riam de mim!)

A2: Boa pergunta!

A3: Sempre ficava me perguntando o que seria esse vácuo que todo mundo fala em Ciência.

A4: Estou gostando muito de participar dessa formação, estamos conseguindo falar sobre coisas simples que em um grupo maior por vergonha eu jamais perguntaria. Mas também tenho dúvidas.

A5: Eu também! Penso o vácuo como algo palpável. E confesso! Sempre quis perguntar isso. (abaixando a cabeça nesse momento)

P: Fico muito contente que estão perdendo a vergonha, e confiando em nosso grupo para realizar todas as perguntas, perguntem mesmo!

P: Existem dois tipos de ondas: as que precisam de um meio de propagação, denominadas de ondas mecânicas, e as que não precisam de um meio para propagarem-se, chamadas de ondas eletromagnéticas.

A2: Estou começando a compreender 
Research, Society and Development, v. 11, n. 1, e32611124848, 2022

(CC BY 4.0) | ISSN 2525-3409 | DOI: http://dx.doi.org/10.33448/rsd-v11i1.24848

\section{A3: Está fazendo sentido o experimento.}

A4: Ondas em cordas, ondas do mar e ondas sonoras são classificadas como mecânicas. Luz, raios x, ondas e ondas de rádio são classificadas como eletromagnéticas.

A5: Gente! Como um experimento tão simples compreendendo os conceitos podem auxiliar na aprendizagem, está fazendo todo sentido pra mim. Estava me sentindo como aqueles alunos que não entendiam nada.

P: Analisando o som não pode propagar-se no espaço, pois, nesse ambiente, existe o vácuo. De uma forma mais simples, vácuo é a condição de um local completamente vazio, sem a presença de quase nenhum tipo de matéria como líquidos, sólidos, gases e até mesmo o ar.

A1: Agora entendi, e ficou mais claro a realização do experimento e estamos explorando uma onda mecânica. Sempre fico boiando nos experimentos de Ciências, por não compreender que não uso em sala de aula.

A4: Então o som não pode se propagar no vácuo, pois não há matéria que propague a energia das ondas sonoras. (eu achava que era possível).

A5: O som não pode se propagar no espaço, analisando o experimento posso ver que por não existir moléculas no ambiente, as ondas sonoras não são transmitidas.

Como a discussão ficou bem interessante nesse momento, disponibilizamos mais dois vídeos. E questionamos os participantes com a seguinte pergunta: Ondas são perturbações geradas no espaço e são capazes apenas de transportar energia, sem transportar matéria?

A1:Sim, as ondas não produzem matéria só propaga energia. (montando meu experimento percebi claramente isso)

A2: Sim, pois as ondas podem ser de natureza mecânica, eletromagnética e gravitacional. Elas transportam exclusivamente energia e não a matéria. (Em minha mente vejo o experimento)

A3: As ondas transportam energia e não transportam matéria, quando testei o experimento consegui visualizar claramente esse processo ( $O$ experimento me ajudou a perceber essa relação)

A4: Sim, a onda sonora é a movimentação constante - de vai e vem - da matéria sem deslocá-la, e que provoca a mesma movimentação na matéria ao seu redor (geralmente o ar, lembrei quando estava executando o experimento).

A5: Pode, pois, ondas não transportam matéria, apenas energia. (Quando terminei de realizar o experimento fiquei uns bons momentos analisando seu funcionamento, algo tão simples, mas que é capaz de promover tantas reflexões).

Ao finalizar o segundo encontro somos capazes de perceber a importância da experimentação na compreensão de conceitos. "A utilização de experimentos como ponto de partida, para desenvolver a compreensão de conceitos, é uma forma de levar o aluno a participar de seu processo de aprendizagem" (Pereira, 2010, p. 5). Fato esse que se comprova quando analisamos as falas dos docentes, e as relações desenvolvidas entre o conhecimento adquirido e o funcionamento do experimento. 
Research, Society and Development, v. 11, n. 1, e32611124848, 2022

(CC BY 4.0) | ISSN 2525-3409 | DOI: http://dx.doi.org/10.33448/rsd-v11i1.24848

\section{Análise do Terceiro Momento}

No encontro seguinte, refletimos sobre o problema proposto e iniciamos o terceiro momento "Agindo sobre os objetos para ver como eles reagem". Foram apresentadas as seguintes falas:

P: Quais dificuldades foram apresentadas na montagem do experimento?

A1: Pude perceber que preciso para me mexer tanto com EVA, e que as medidas da massa das bolinhas devem ser respeitas para que o movimento ocorra perfeitamente.

A2: Notei que é importante realizar e medição entre os espaços de cada palitinho de churrasco, não medi direito precisei refazer o experimento.

A3: Para não me perder as medidas usei o palito de churrasco como base, assim marquei exatamente a medida e realizei o distanciamento correto.

A4: Concordo todos, o que senti dificuldade foi no momento de colar as massinhas de modelar para formar o contrapeso na ponta que espeta do palito, prefiro cortar as pontas.

A5: Pra mim foi quando precisei usar a fita para colar os palitos, achei que não iria segurar passei duas vezes a fita. Não segui os passos colei as bolinhas antes de passar a fita. Ficou muito ruim. Precisei refazer o experimento. (Acostumada com EVA, Risos!)

P: Com o auxílio do seu experimento e dos vídeos de apoio disponibilizados. Qual a natureza da onda produzida no experimento?

A1: Onda mecânica e de vibração transversal. (Estou tão emocionada!)

A2: Mecânica pois ela carrega energia em um meio para se propagar.

A3: Pude perceber que é mecânica, e se é mecânica precisa de um meio para se propagar então ondas mecânicas não se propagam no vácuo.

A4: A onda gerada é mecânica e digo mais, é transversal pois as vibrações são perpendiculares.

A5: Quando provoquei a perturbação gerei uma onda mecânica.

P: Concordam com a afirmação de A3, quando ela diz que ondas mecânicas não se propagam no vácuo?

A: Sim! (Resposta geral dos participantes)

A1: Então ondas mecânicas é uma coisa e ondas eletromagnéticas são outras?

P: Existem diferenças entre ondas mecânicas e eletromagnéticas?

A2: Mecânicas precisam de um meio material para se propagar.

A3: A eletromagnéticas não precisam de um meio material para se propagar.

A1: Em nosso livro didático não trazem essas definições, eu sempre me confundia. Antes eu imaginava que as duas se propagavam sem levar em consideração o meio material.

A: Verdade (Resposta geral dos participantes).

A4: No manual do professor deveriam tem explicações mais científicas sobre esse assunto, afinal não sabemos tudo e na hora do planejamento esse conhecimento é muito importante.

A5: Concordo com vocês, e gostei da pergunta da Al, afinal quando pegamos nossos materiais, aparecem várias imagens aos alunos, de rádio, celular, antenas e crianças brincado de corda e para nós era tudo ondas e somente ondas, hoje conseguimos perceber a diferença. (gente estou chocada. RS!) 
Esse encontro foi realizado de maneira síncrona. Os docentes em geral apresentaram dificuldades em alguns momentos relacionados a montagem do experimento, conforme podemos observar nas falas acima, porém se sentiram desafiados e motivados analisando o erro de maneira positiva e construtiva.

Rosso destaca que

A análise do erro permite-nos valorizar o processo mental subjacente às respostas dadas e não apenas a resposta como um produto que se encerra em si mesmo. A análise dos processos utilizados pelo aluno nos leva a verificar que há algo de positivo nele mesmo quando erra (Rosso, 1996).

Vale ressaltar que a partir do erro, eles conseguiram analisar minuciosamente os efeitos produzidos no decorrer da execução do experimento. Chamamos a atenção que esse momento foi de extrema valia para os docentes uma vez que eles conseguiram perceber alguns erros conceituais desenvolvidos em suas próprias aulas.

\section{Análise do Quarto Momento}

$\mathrm{O}$ quarto momento estruturou-se pelo estudo das ondas transversais e longitudinais. Nesse encontro esses tipos de ondas, bem como suas devidas definições foram apresentadas em forma de vídeos explicativos experimentais (Anexo A). Passamos para o momento “Tomando consciência de como foi produzido o efeito desejado". Sendo questionados com a seguinte pergunta:

P: O que são ondas? Existe diferenças entre a direção de propagação e de vibração?

A1: Agora eu consigo responder, ondas são perturbação que necessitam de um meio material para se propagar.

A2: Não podemos esquecer que elas transportam energia.

A3: Analisando os vídeos pude perceber que não importa a sua natureza, forma de propagação ou perturbação, todas as ondas apresentam as mesmas propriedades: frequência, comprimento de onda, amplitude, velocidade e período.

A4: Outro ponto importante é que as ondas não transportam matéria.

A5: Ondas mecânicas não se propagam no vácuo, mas as eletromagnéticas sim, pois não precisam de um meio de propagação.

P: E quanto ao meio de direção e propagação?

A3: Elas podem se propagar em cordas, no ar e na água.

A2: Podem ser classificadas em unidimensionais, bidimensionais e tridimensionais.

A1: Mas só podemos classificar em unidimensionais, bidimensionais e tridimensionais, quando estamos analisando a direção de propagação.

A2: Bem lembrado!

A4: Mas quando pensamos na direção de propagação podemos classificar em ondas transversais e longitudinais.

A5: E quando as vibrações apresentam caraterísticas transversais e longitudinais, podemos classificar como ondas mistas.

P: Vocês conseguiram me dar um exemplo de ondas mistas?

A: Ondas do mar (Resposta geral dos participantes).

Fica evidente nessas falas, que aos poucos os docentes foram melhorando suas explicações, falas como a do A1 nos revelam isso: "Foi possível perceber que as ondas são classificadas relacionando sua natureza, direção de propagação e 
vibração. Gostei muito de analisar os vídeos disponibilizados, linguagem simples e não é cansativo." Podemos perceber que todos os participantes conseguiram compreender que as ondas do mar são classificadas como ondas mistas.

\section{Análise do Quinto Momento}

Dando continuidade à nossa investigação, o pesquisador apresentará as aplicações sobre estudo do som utilizando um simulador do PHET - Colorado, para que os docentes explorem os conceitos os conceitos básicos relacionados ao som. Esse recurso foi aplicado na etapa "dando explicações causais" Vejamos as explicações dos pesquisados ao simular a propagação do som em diversos meios materiais.

A1: Eu nunca tinha usado um simulador online antes, que recurso bacana.

P: Com qual frequência usam simulações em suas aulas?

A: Nunca (Resposta geral dos participantes).

A3: Imaginei que era tão complicado usar os simuladores.

A4: E na escola estamos com o projetor disponível, mas quando ouvia falar em simulações pensava que somente no Ensino Médio era possível usar.

A2: Estou encantada com os simuladores, e feliz em saber que existe um site gratuito com diversos conteúdos para simulamos. (que emoção)

A5: Olha! Podemos trabalhar diversos conteúdos em sala com esse recurso.

A1: Percebi que é possível ensinar conteúdos de física para crianças com os simuladores, mostram como acorrem os efeitos.

Consideramos esse momento como muito significativo para os docentes, para eles usar simulações online era possível somente com alunos do Ensino Médio. É possível perceber que não faziam uso desse recurso por desconhecer suas potencialidades e não foram orientados onde poderiam encontrar as simulações na internet. "O simulador é uma hipermídia que naturalmente apresenta características investigativas e com um roteiro estruturado essas características foram potencializadas" (Gregório et al., 2016, p. 121). Vejamos agora alguns trechos do momento "dando explicações causais"

P: Vejamos o simulador, estamos nesse momento analisando ondas sonoras, ao alterar a amplitude e a frequência na simulação. O que perceberam?

A1: Estamos falando de uma onda mecânica. Certo?

A2: E longitudinal

A4: Isso, é longitudinal porque o movimento das partículas é paralelo à direção de propagação da onda.

A3: Cada vez que altero a frequência olho no gráfico e percebo que a onda repete em um intervalo de um segundo.

A5: Então estamos falando de uma onda periódica.

P: Veja bem, observem na simulação, quanto menor é a frequência de uma onda sonora, qual percepção sonora percebemos?

A5, A3, A2: O som fica mais alto?

Al e A4: Não, ele fica mais grave, veja bem como as ondas estão se comportando na simulação.

A2: Verdade!

A5: Não prestei a atenção na simulação. Agora faz todo sentido.

A3: Olhando aqui entendi. 
P: Então, quanto maior a frequência de uma onda sonora, qual percepção sonora percebemos?

A: Agudo! (Resposta geral dos participantes).

A3: Para tudo! Então quer dizer que esse valor $344 \mathrm{~m} / \mathrm{s}$ que aparece aqui na simulação como uma constante é a velocidade do som?

P: Perfeito.

A: Aplausos (Resposta geral dos participantes)

A2: Foca em mim! Então posso afirmar que a amplitude está relacionada ao volume do som?

P: Ótimo

A: Aplausos (Ação geral dos participantes)

A1: Ficou claro pra mim que por isso que amplitude e frequência podem ser considerada duas características básicas das ondas sonoras.

A5: Concordo senão no gráfico elas não estariam nos eixos $x$ e y.

$P$ : E quando analisamos a luz?

A1: Aqui é uma onda eletromagnética.

A2: Ela é uma onda que podemos enxergar.

A3: Percebi que a frequência mede a oscilação.

A5: Que ela sofre a cada segundo

A4: Não precisam do meio material para se propagarem.

Percebe-se que o trabalho com o simulador, bem como os vídeos disponibilizados no decorrer das simulações, foi de extrema importância para o desenvolvimento da aprendizagem de conceitos, pois ficou evidente no quinto momento da sequência didática, "Dando explicações causais", que os docentes conseguiram por meio da reflexão das variáveis manipuladas, pela argumentação, e também pela socialização de ideias no grupo, significaram de forma coerente a os conceitos básicos relacionados ao som.

Também ficou claro que os docentes desenvolveram novos raciocínios, novas forma de análise e explicações mais fundamentadas que auxiliaram compreensão do fenômeno. Uma prova de tal fato foi que, após exploramos as simulações, os participantes passaram a explicar o fenômeno estudado, mesmo que de forma simplificada, pelo conceito de classificação de ondas. "[...] o aluno não só relembra o que fez, como também colabora na construção do conhecimento que está sendo sistematizado" (Carvalho,2013, p. 12). Assim para finalizamos essa etapa, provocarmos os docentes com a seguinte pergunta:

P: Porque "fazer a ola" em um estádio pode ser considerado um exemplo de onda transversal?

A1: Afs! Nunca tinha pensado isso.

A2: Boa pergunta

A3: Vamos lá gente, todos se levantam juntos certo!

A4: Hum!!! Então a "ola” é uma perturbação.

P: Isso!

A5: A caraterística de uma onda transversal consiste nas vibrações perpendiculares á direção de propagação.

A: Lembramos disso no vídeo que demostrou as ondas quanto a sua direção (Todos concordaram)

A1: Perai! Podemos dar como exemplo ondas nas cordas e pensamos no que aconteceu durante nossa atividade experimental. 
Research, Society and Development, v. 11, n. 1, e32611124848, 2022

(CC BY 4.0) | ISSN 2525-3409 | DOI: http://dx.doi.org/10.33448/rsd-v11i1.24848

A2: Se pensamos nas ações quando realizamos a atividade experimental, ao fazer a "ola" estamos pensando em uma perturbação que se desloca horizontalmente de uma pessoa a seguinte de cada fileira.

P: Muito bem

A5: Não podemos esquecer que não estão transportando matéria.

A3: Outro fato interessante que eles me movem verticalmente para cima.

A4: E também perpendicular á direção que a onda se propaga.

P: Gostei muito das definições que apresentaram.

A: Aplausos (Ação geral dos participantes)

Ficou claro que essa etapa da investigação, em que foram questionados sobre uma situação do dia-a-dia, conduziu os professores a melhor entender o processo ocorridos nos experimentos e nas simulações. Essa afirmativa vem do fato de os participantes terem compreendido. Os conceitos básicos relacionados as ondas como a sua natureza, direção de propagação e vibração

\section{Análise do Sexto Momento}

Dando continuidade à pesquisa, chegamos à atividade final da formação continuada. Em primeiro momento trabalhos o vídeo "O que é o som? Como o som se propaga", e também a leitura do texto "Percepções sonoras". Vejamos as explicações dos docentes após o uso desses recursos didáticos, que foram utilizados como sistematização e contextualização social dos conteúdos. A pergunta, basicamente, foi a seguinte: O que é o som?

A1: Posso dizer que o Som é uma um tipo de vibração que propaga pelo ar, transmitindo energia. (lembrei do experimento).

A2: Vou definir com base no momento da realização do simulador. Pra mim o som é uma onda que se propaga no ar dependendo das vibrações das moléculas. (Vejo em minha mente as moléculas do simulador vibrando)

A3: O som é uma onda mecânica, pois só é capaz de propagar-se em meios físicos como ar, água, metal, o experimento, o simulador e vídeos me ajudaram muito a perceber essas características.

A4: Posso dizer que o som é uma onda longitudinal, percebi com o experimento e com a simulação que ele se propaga na mesma direção da vibração responsável por produzi-lo.

A5: O som é uma onda mecânica e longitudinal e precisa do meio físico para se propagar, o experimentos, a simulação e as discussões me ajudaram a fazer essa definição.

O curso ofertado auxilia de forma positiva a evolução conceitual dos docentes, podemos perceber nas falas que conseguiram compreender os conceitos básico relacionados ao o som, sua natureza, sua direção de propagação e direção de vibração. Tomamos o cuidado no momento de elaborar cada etapa, proporcionando momento de discussão e exploração do conteúdo. No quadro 11 temos a comparação das respostas da pergunta realizada do início e no final da sequência investigativa: O que é o som? levando em consideração as categorias inicias da análise. 
Quadro 11: Análise das categorias das respostas dos docentes.

\begin{tabular}{|c|c|c|}
\hline Categorias de análise & Resposta inicial & Resposta final \\
\hline $\begin{array}{l}\text { Desconhecimento } \\
\text { conteúdo }\end{array}$ & $\begin{array}{l}\text { A4:O som são vibrações transmitidas somente com uso } \\
\text { de objetos. (é o que falaria para meu aluno. Rs!) }\end{array}$ & \\
\hline $\begin{array}{l}\text { Características senso comum } \\
\text { do conteúdo }\end{array}$ & $\begin{array}{l}\text { A1: Eu acho que são vibrações e pressão do ar que } \\
\text { está a nossa volta. (Acho que é isso!) } \\
\text { A2: Hum!!!, pode ser uma de propagação de ondas? } \\
\text { A3: É movimentação ondulatória constante da } \\
\text { matéria. (é o que eu acho) } \\
\text { A5: Pra mim o som ocorre somente entre objetos } \\
\text { vibrantes, e se propagam também nas cordas vocais. } \\
\text { (Certo?) }\end{array}$ & \\
\hline $\begin{array}{lll}\text { Atributos } & \text { científico } & \text { do } \\
\text { conteúdo. } & & \end{array}$ & & $\begin{array}{l}\text { A1: Posso dizer que o Som é uma um tipo de vibração que } \\
\text { propaga pelo ar, transmitindo energia. (lembrei do } \\
\text { experimento). } \\
\text { A2:Vou definir com base no momento da realização do } \\
\text { simulador. Pra mim o som é uma onda que se propaga no ar } \\
\text { dependendo das vibrações das moléculas. (Vejo em minha } \\
\text { mente as moléculas do simulador vibrando) } \\
\text { A3: O som é uma onda mecânica, pois só é capaz de } \\
\text { propagar-se em meios físicos como ar, água, metal, o } \\
\text { experimento, o simulador e vídeos me ajudaram muito a } \\
\text { perceber essas características. } \\
\text { A4: Posso dizer que o som é uma onda longitudinal, percebi } \\
\text { com o experimento e com a simulação que ele se propaga na } \\
\text { mesma direção da vibração responsável por produzi-lo. } \\
\text { A5: O som é uma onda mecânica e longitudinal e precisa do } \\
\text { meio fisico para se propagar, o experimentos, a simulação e } \\
\text { as discussões me ajudaram a fazer essa definição }\end{array}$ \\
\hline
\end{tabular}

Fonte: Dados da pesquisa.

Ao analisarmos as respostas disponibilizadas podemos perceber que no início da investigação as respostas dos professores oscilavam entre desconhecimento do conteúdo e características do senso comum do conteúdo. Após cada etapa da sequência investigativa podemos observar que os atributos científicos já estão presentes em suas respostas, o que confirma o potencial das atividades desenvolvidas bem como a eficácia do ensino investigativo na formação docente.

Vejamos algumas das respostas dos participantes sobre quais as contribuições desse módulo em sua prática pedagógica?

A1: Eu nunca tive uma formação continuada que colocássemos a mão na massa, geralmente escutamos muito teoria, pouca prática. Os conhecimentos aqui aprendidos vão auxiliar muito em sala de aula, tentaria realizar mais experimentos em minhas aulas. Vamos ter mais módulos?

A2: Eu gostei muito de compreender os passos do ensino investigativo, pra mim investigar era passar a questão no quadro, e ver as respostas dos alunos. Achei os passos muito interessantes e quero implantar em minhas aulas.

A3: Gostei muito. Foi muito bom compreender os passos do ensino investigativo e as discussões foram muito boas, poderíamos ter mais formações assim com poucas pessoas, aprendemos mais. Gostaria de aprimorar mais meus conhecimentos.

A4: Adorei as discussões e principalmente que estávamos em poucas pessoas, tivemos oportunidade de expor nossas ideias e juntos desenvolver nossa aprendizagem. Com a formação consegui encontrar alguns conceitos no livro 
Research, Society and Development, v. 11, n. 1, e32611124848, 2022

(CC BY 4.0) | ISSN 2525-3409 | DOI: http://dx.doi.org/10.33448/rsd-v11i1.24848

didático muito superficial, no livro do professor deveriam disponibilizar mais elementos para trabalhar esse conteúdo. Quero usar o que aprendi com meus alunos. Teremos mais formações assim?

A5: Percebi que preciso estudar mais, adorei montar experimento, construir um material pedagógico que posso usar em sala de aula, fantástico os simuladores. Quero estudar mais sobre esse tema.

Com esse relato podemos perceber o quanto formação continuada auxilia diretamente na evolução conceitual e aprimoramento das ações pedagógicas. Podemos ressaltar que as atividades exploradas pelos docentes em cada passo da sequência didática foram capazes de contribuir para uma formação mais reflexiva, pois, os participantes conseguiram reconhecer o pouco conhecimento que tinham sobre o som, e muitos deles eram do senso comum. Os docentes demonstraram sua satisfação nos relatos disponibilizados, solicitando mais momentos como esse, mais experimentos, mais formações com base no ensino investigativo.

\section{Considerações Finais}

Com os dados da presente pesquisa, podemos perceber o quanto se faz necessária oportunizar mais formações continuadas nas redes municipais de ensino explorando o ensino investigativo como ferramenta para promover a evolução conceitual entre os docentes. Essa assertiva se confirma à medida que os participantes agiram como protagonistas ativos na construção da aprendizagem, isto é, participando ativamente de cada etapa investigativa.

Os fenômenos relacionados ao som despertam o interesse e a curiosidade nas crianças, jovens adultos pois seus conceitos estão no cotidiano, e podemos facilmente relacionar com exemplos práticos como: Ondas de rádio, luz, raio X, entre outros. Ainda assim, esse tema é pouco discutido ou nada discutido nos cursos de capacitação e formação continuada para os docentes que lecionam nos anos iniciais do Ensino Fundamental.

A análise dos dados revelou que os docentes, quando estimulados a participar de atividades investigativas, desenvolvem seus conhecimentos conceituais de forma compreensiva, o que é muito bom para que ocorra a evolução conceitual. Tal feito foi alcançado por meio das seguintes habilidades apresentadas no decorrer da pesquisa, podemos citar: o raciocínio, a flexibilidade e argumentação.

Levando-se em consideração que os fenômenos sonoros estão contemplados na BNCC e no CREP, documentos que norteiam o ensino de Ciências em nosso estado, entendemos que a formação inicial desse docente precisa fornecer o mínimo de condições para que o futuro professor se sinta capacitado para ensiná-los. Isso pode ser garantido em parte pela inclusão dos fundamentos teóricos e práticos sobre o tema na formação inicial do professor por meio dessa sequência apresentada. "Em poucas palavras: para se ensinar conteúdos, é necessário conhecer bem esses conteúdos” (BRASIL, 2017, p. 321).

Podemos perceber que ficou evidenciado que o ensino por investigação é capaz de promover no corpo docente a construção da autonomia e a evolução conceitual sobre o assunto explorado. Essa atitude ficou clara no decorrer da pesquisa no momento em que os pesquisados, motivados pelo desejo de saber as reações que suas ações ocasionariam nos objetos, interferiram em situações e opinaram em discussões sem medo de errar.

Assim, buscamos por meio desse trabalho contribuir com o debate do desenvolvimento de conceitos básico sobre o som nos Anos Iniciais do Ensino Fundamental, bem como contribuir com a seleção de recursos didáticos para os profissionais que desejam incluir o tema em suas aulas. Seria de grande valia oportunizar grupos de pesquisas nas redes municipais ficado no ensino investigativo junto aos professores atuantes nos Anos Inicias, discutindo sobre quais as vantagens e fragilidades do uso do ensino investigativo no ensino remoto, hibrido e até mesmo o presencial, fica evidente que no decorrer da investigação os docentes demostram interesse em buscar e entender essa metodologia de ensino bem como o tema abordado nesse trabalho. 
Research, Society and Development, v. 11, n. 1, e32611124848, 2022

(CC BY 4.0) | ISSN 2525-3409 | DOI: http://dx.doi.org/10.33448/rsd-v11i1.24848

\section{Referências}

Azevedo, M. C. P. S. (2004). Ensino por investigação: problematizando as atividades em sala de aula. Ensino de ciências: unindo a pesquisa e a prática. Pioneira Thomson Learning, 3, 19-33.

Azevedo, M. N. D. (2008). Pesquisa-ação e atividades investigativas na aprendizagem da docência em ciências (Doctoral dissertation, Universidade de São Paulo).

Bardin, L. (1977). Análise de conteúdo. Lisboa: edições, 70, 225.

Bizzo, N. (2002). Perspectivas para a atuação do Professor-Ciências: fácil ou difícil?.

Brasil (2017). Base Nacional Comum Curricular. Ministério da Educação. Brasília: Secretaria da Educação Básica.

Brasil (2018). Base Nacional Comum Curricular. Ministério da Educação. Brasília: Secretaria da Educação Básica.

Brito, T. A. D. (2003). Música na educação infantil. São Paulo: Peirópolis, 2.

Carvalho, A. D., Vannucchi, A. I., Barros, M. A., Gonçalves, M. E. R., \& Rey, R. D. (1998). Ciências no ensino fundamental: o conhecimento físico. São Paulo: Scipione, 7-16.

Carvalho, A. M. P. (2004). Ensino de Ciências-unindo a pesquisa e a prática. Cengage Learning Editores.

Carvalho, A. D. (2004). Critérios estruturantes para o ensino das ciências. Ensino de ciências: unindo a pesquisa e a prática. São Paulo: Pioneira Thomson Learning, 1-17.

Carvalho, A. M. P. D. (2013). O ensino de ciências e a proposição de sequências de ensino investigativas. Ensino de ciências por investigação: condições para implementação em sala de aula. São Paulo: Cengage Learning, 1, 1-19.

Carvalho, A. M. P. D. (2013). Ensino de ciências por investigação: condições para implementação em sala de aula. São Paulo: cengage learning, 164.

Chassot, A. I. (1990). A educação no ensino da química. Unijuí.

Chassot, A. (2003). Alfabetização científica: uma possibilidade para a inclusão social. Revista brasileira de educação, 89-100.

Cogo, T.C \& Leite, F.R. (2019). Ensino de Ciências por investigação: Uma análise conceitual da BNCC. In: $2^{o}$ Congresso Internacional da FAG; $7^{o}$ Congresso de Educação da FAG, $7^{\circ}$, Cascavel Paraná. < https://www.fag.edu.br/congressoeducacao/anais-2019 >.

Coll, C., \& Monereo, C. (2010). Psicologia da Educação Virtual: Aprender e ensinas com as tecnologias da informação e da comunicação. Artmed Editora.

Couto, M. E. S. (2005). Aprendizagem da docência de professores em curso de formação continuada na modalidade a distância. In VIII CONGRESSO ESTADUAL PAULISTA SOBRE FORMAÇÃO DE EDUCADORES (pp. 14-23).

Creswell, J. W. (2014). Investigação Qualitativa e Projeto de Pesquisa-: Escolhendo entre Cinco Abordagens. Penso Editora.

Grandy, R. E., \& Duschl, R. A. (2007). Reconsidering the Character and Role of Inquiry in School Science: Analysis of a Conference12.

Gregório, E. A., de Oliveira, L. G., \& de Matos, S. A. (2016). Uso de simuladores como ferramenta no ensino de conceitos abstratos de Biologia: uma proposição investigativa para o ensino de síntese proteica. Experiências em ensino de Ciências, 11(1), 101-125.

Magalhães Júnior, C. A. D. O., \& Pietrocola, M. (2011). Atuação de professores formados em licenciatura plena em Ciências. Alexandria: revista de educação em ciência e tecnologia, 4(1), 175-198.

Marconi, M. D. A. \& Lakatos, E. M. (2006). Técnicas de pesquisa: planejamento e execução de pesquisas, amostragens e técnicas de pesquisa, elaboração, análise e interpretação de dados. 6 edição. São Paulo: Atlas.

Minayo, M. C. S., Deslandes, S. F., \& Gomes, R. (2011). Pesquisa social: teoria, método e criatividade. Editora Vozes Limitada.

Muline, L. S. (2018). O ensino de Ciências no contexto dos anos iniciais da escola fundamental: a formação docente e as práticas pedagógicas (Doctoral dissertation).

Neves, J. L. (1996). Pesquisa qualitativa: características, usos e possibilidades. Caderno de pesquisas em administração, São 1(3), 1-5.

Paraná (2020). Crep - Currículo da Rede Estadual Paranaense. Secretaria de Estado da Educação. Superintendencia de Educação.: SEED/PR.

Pereira, B. B. (2010). Experimentação no ensino de ciências e o papel do professor na construção do conhecimento. Cadernos da FUCAMP, 9(11).

Phet (2021) Interactive Simulations da Universidade do Colorado.

Reginaldo, C. C., Sheid, N. J., \& Güllich, R. I. D. C. (2012). O ensino de ciências e a experimentação. Anaped Sul: Seminário de Pesquisa em Educação da Região Sul, Giruá, 1-13.

Rosa, C. W., Perez, C. A. S., \& Drum, C. (2016). Ensino de física nas séries iniciais: concepções da prática docente. Investigações em ensino de ciências, 12(3), 357-368. 
Research, Society and Development, v. 11, n. 1, e32611124848, 2022

(CC BY 4.0) | ISSN 2525-3409 | DOI: http://dx.doi.org/10.33448/rsd-v11i1.24848

Rosso, A. J. (1996). A função formativa do erro. Espaço Pedagógico, Passo Fundo, 3(1), 79-95.

Schneider, D. R., Franco, S. R. K., \& Sabrito, C. E. S. (2017). Atividades de Ensino no Moodle: Implicações da Fluência Tecnológica Digital do Professor. RENOTE, 15(1).

Schön, D. A. (Ed.). (1991). The reflective turn: Case studies in and on educational practice (Vol. 131). Teachers College Press.

Severino, A. J. (2017). Metodologia do trabalho científico. Cortez editora.

Silva Junior, E. F. (intr) (2010). Física: ensino médio. Positivo

Soffa, M. M., \& Torres, P. L. (2009). O processo ensino-aprendizagem mediado pelas tecnologias da informação e comunicação na formação de professores on-line. In IX Congresso Nacional de Educação-EDUCERE. PUCRS.

Unesco Brasil (2005) Ensino de Ciências: o futuro em risco.: http://unesdoc.unesco.org/images/0013/001399/139948por.pdf.

Valente, J. A. (1995). Informática na educação: confrontar ou transformar a escola. Perspectiva, 13(24), 41-49.

Viecheneski, J. P., \& Carletto, M. (2013) Revista Brasileira de Ensino de Ciência e Tecnologia. (R. B. E. C. T.), 6(2), $213-227$.

Zabala, A. (1998). A prática educativa: como ensinar. trad. Ernani F. da F. Rosa. ArtMed. 